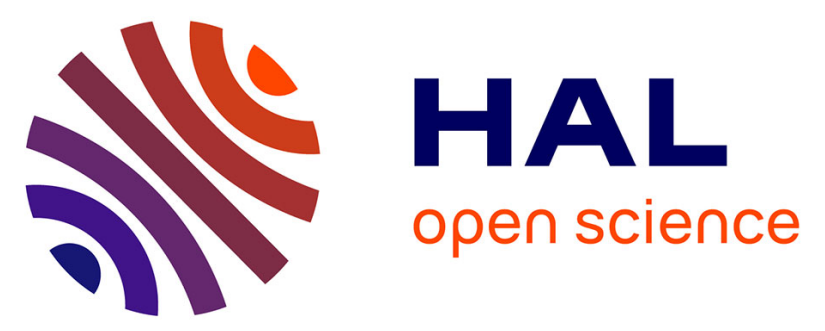

\title{
Effects of bioturbation by tubificid worms on biogeochemical processes, bacterial community structure and diversity in heterotrophic wetland sediments
}

Marie Cariou, Clémentine François, Jérémy Voisin, Mathilde Pigneret, Frédéric Hervant, Laurence Volatier, Florian Mermillod-Blondin

\section{To cite this version:}

Marie Cariou, Clémentine François, Jérémy Voisin, Mathilde Pigneret, Frédéric Hervant, et al.. Effects of bioturbation by tubificid worms on biogeochemical processes, bacterial community structure and diversity in heterotrophic wetland sediments. Science of the Total Environment, 2021, 795, pp.148842. 10.1016/j.scitotenv.2021.148842 . hal-03286860

\section{HAL Id: hal-03286860 https://hal.science/hal-03286860}

Submitted on 18 Oct 2021

HAL is a multi-disciplinary open access archive for the deposit and dissemination of scientific research documents, whether they are published or not. The documents may come from teaching and research institutions in France or abroad, or from public or private research centers.
L'archive ouverte pluridisciplinaire HAL, est destinée au dépôt et à la diffusion de documents scientifiques de niveau recherche, publiés ou non, émanant des établissements d'enseignement et de recherche français ou étrangers, des laboratoires publics ou privés. 
Effects of bioturbation by tubificid worms on biogeochemical processes, bacterial community structure and diversity in heterotrophic wetland sediments

Authors: Marie Cariou, Clémentine M. Francois, Jérémy Voisin, Mathilde Pigneret, Frédéric Hervant, Laurence Volatier, Florian Mermillod-Blondin

Corresponding author: Florian Mermillod-Blondin

Univ Lyon, Université Claude Bernard Lyon 1, CNRS, ENTPE

UMR 5023 LEHNA (Laboratoire d'Ecologie des Hydrosystèmes Naturels et Anthropisés)

6, rue Raphaël Dubois - Bât. Forel F-69622 Villeurbanne Cedex FRANCE

(+33) 0472431364

florian.mermillod-blondin@univ-lyon1.fr

Affiliation: Univ Lyon, Université Claude Bernard Lyon 1, CNRS, ENTPE, UMR 5023 LEHNA, F-69622, Villeurbanne, France 


\begin{abstract}
:
Bioturbation activity of tubificid worms has been recognized as a key process influencing organic matter processing and nutrient cycling in benthic aquatic ecosystems. This activity is expected to modify benthic microbial communities by affecting the physical and chemical environment in sediments. Nevertheless, quantifications of bacterial community changes associated with bioturbation in freshwater ecosystems are still lacking. The present study aimed at evaluating the impact of tubificid worms on bacterial community structure using NGS approach (16S metabarcoding) and long (6 months) laboratory experiments on four heterotrophic wetland sediments. Worm bioturbation activity significantly stimulated biogeochemical processes at the water-sediment interface but only had a marginally significant effect on bacterial community structures. Yet, bacterial diversity was consistently reduced in presence of worms. Such decrease could be associated with the stimulation of organic matter mineralization by worms, leading to a reduction of the diversity of trophic niches available for bacterial species. The slight changes in bacterial community structures induced by bioturbation did not appear to control biogeochemical processes. Thus, the stimulation of biogeochemical processes by worm bioturbation was more associated with a stimulation of the initial bacterial community than with a drastic change in bacterial communities induced by worms.
\end{abstract}

\title{
$\underline{\text { Keywords }}$
}

organic matter processing, $\mathrm{CO}_{2}$ fluxes, nutrient fluxes, bacterial communities, diversity and structure, 16S metabarcoding 


\section{$\underline{\text { INTRODUCTION }}$}

Bioturbation by benthic fauna has been recognized as a key process influencing organic matter processing and nutrient cycling in aquatic ecosystems (Aller, 1983; Papaspyrou et al., 2006; Mermillod-Blondin and Lemoine, 2010; Gautreau et al., 2020). Sediment reworking, biogenic structure building (e.g., burrows), and bio-irrigation induced by bioturbating fauna modify pore water chemistry and then have consequences on microbial communities and associated biogeochemical processes (Kristensen et al., 2012; Deng et al., 2020). The impact of bioturbation on biogeochemistry and nutrient dynamics at the water-sediment interface has been evaluated in diverse benthic ecosystems (marine, lacustrine, and river sediments; see the review by Mermillod-Blondin, 2011), but most studies quantifying the interactions between bioturbation processes and microbial community structures focused on marine environments (e.g., Taylor and Cunliffe, 2015). These works showed that bioturbation significantly impacts bacterial community structures by modifying biogeochemical gradients and by increasing the availability of organic matter (e.g., mucus production, transport of fresh organic matter) in sediments (Papaspyrou et al., 2005; Papaspyrou et al., 2006; Cuny et al., 2007; Bertics and Ziebis, 2010; Lukwambe et al., 2018; Dale et al., 2019a; Deng et al., 2020; Hou et al., 2021). For example, Laverock et al. (2010) demonstrated that bacterial communities from irrigated burrows of the ghost shrimp were more diversified than bacterial communities from nonbioturbated sediments. In oil-contaminated coastal sediments, Taylor and Cunliffe (2015) also showed that burrows of the polychaete Hediste (Nereis) diversicolor harbored different bacterial and eukaryotic communities compared with non-bioturbated sediments. Moreover, bacterial community changes induced by bioturbating fauna in oil-contaminated sediments are expected to favor the presence of bacteria supporting natural bioremediation processes (Cuny et al., 2007; Taylor and Cunliffe, 2015). Therefore, changes in bacterial community structure induced by bioturbating fauna could have a significant influence on benthic ecosystem functioning, but evidence of such mechanism is still lacking (but see the paper of Taylor and Cunliffe (2015) showing a bioturbation-induced increase of obligate hydrocarbonoclastic bacteria genera associated with an enhanced hydrocarbon degradation).

In comparison with marine systems, interactions between bioturbation and microbial community structures have been poorly studied in freshwater ecosystems despite the documented significant contribution of bioturbation on biogeochemical processes in lakes and wetlands (e.g., Svensson et al., 2001; Mermillod-Blondin et al., 2008; Hölker et al., 2015; Baranov et al., 2016). In these systems, tubificid worms are recognized as main "ecosystem engineers" modifying the physical environment by their bioturbation activities (ingestion- 
egestion mechanism, sediment reworking and gallery building; McCall and Fisher, 1980; Navel et al., 2011). By ingesting fine particles at depth and egesting fecal pellets at the sediment surface, tubificid worms modify sediment stratigraphy (McCall and Tevesz, 1982; Ciutat et al., 2006; Li et al., 2016; Pigneret et al., 2016) but also bacterial abundances among sedimentary layers (Wavre and Brinkhurst, 1971; Mermillod-Blondin et al., 2002). Indeed, Wavre and Brinkhurst (1971) measured a significant decrease in the abundance of bacteria associated with fecal pellets compared to those associated with ingested sediments, due to their passage through the digestive tract. The building of gallery networks by worms also increases water-filled porosity and water exchanges at the water-sediment interface, influencing pore-water chemistry (Krantzberg 1985; Anschutz et al. 2012), microbial activity (Mermillod-Blondin et al., 2018), organic matter processing (Navel et al., 2012) and nutrient cycling (Chatarpaul et al., 1980; Nogaro and Burgin, 2014). As observed with marine bioturbating fauna (Papaspyrou et al., 2006; Laverock et al., 2010; Taylor and Cunliffe, 2015), it can be expected that geochemical changes associated with biogenic structures of tubificid worms would also dramatically change bacterial community structure. Nevertheless, this expectation has never been observed in the few laboratory experiments evaluating the interactions between tubificid worms and bacterial community structure. Using T-RFLP (Terminal Restriction Fragment Length Polymorphism) and cloning library analyses, Zeng et al. (2014) did not detect any significant impact of tubificid worms on the bacterial community structure of lake sediments although they noticed an increased proportion of Betaproteobacteria in the bacterial community bioturbated by worms. Using a fingerprint approach (ARISA), Mermillod-Blondin et al. (2013) also reported a low impact of tubificid worms on bacterial community structure of river sediments. Then, the stimulation of organic matter processing and associated microbial activities by tubificid worms reported in the same experiment (Mermillod-Blondin et al., 2013) was attributed to a stimulation of the present bacterial community rather than a drastic change of this bacterial community. However, these previous studies were performed in laboratory experiments of around one month, a duration which is not necessarily long enough to detect a significant change in bacterial community structure. In line with this argument, Huang et al. (2016) developed an experimentation of two months that demonstrated that tubificid worm bioturbation could affect the community structure of ammonia-oxidizing bacteria of lake sediments. Moreover, influence of bioturbating tubificid worms on bacterial community structures have never been investigated using Next Generation Sequencing (NGS) approaches that are more accurate and exhaustive than fingerprint approaches (T-RFLP and ARISA) for identifying bacterial groups. 
Therefore, the present study aimed at filling these gaps by evaluating the role of bioturbating tubificid worms (specimens of the species Limnodrilus hoffmeisteri) on heterotrophic bacterial community structure in sediments using NGS approach (16S metabarcoding) and long (six months) laboratory experiments. The experiments were run with four wetland sediments and their associated heterotrophic bacterial communities to evaluate whether the influence of tubificid worms on bacterial communities would be community/sediment-dependent. In parallel, we measured biogeochemical processes at the water-sediment interface $\left(\mathrm{CO}_{2}\right.$ fluxes reflecting organic matter mineralization; and nutrient $-\mathrm{NH}_{4}{ }^{+}, \mathrm{NO}_{3}{ }^{-}, \mathrm{PO}_{4}{ }^{3-}-$ fluxes at the watersediment interface) to determine whether changes in bacterial community structure may control/drive ecosystem processes. By analyzing bacterial community structures at the sediment surface $(0-1 \mathrm{~cm})$ and in "deep" sediment layer $(4-5 \mathrm{~cm})$, the present experiment aimed at discriminating the potential impact on bacterial communities of fecal pellet egestion at the sediment surface from the influence of biogenic structures produced by worms in deep sediment layer. The present study allowed to test four hypotheses:

(1) As observed in previous studies (e.g., Pigneret et al., 2016), tubificid worms are expected to stimulate biogeochemical processes at the water-sediment interface of the four sediments. (2) Bioturbating activities are expected to modify sedimentary bacterial community structure;

(3) Bacterial community diversity is expected to decrease at the sediment surface due to ingestion-egestion mechanisms (passage through the digestive tract). In contrast, biogenic structures associated changes in geochemical gradients are expected to increase bacterial diversity in deep sediment layer;

(4) In addition, the present study would determine for the first time whether the expected stimulation of biogeochemical processes by worms was mediated by a drastic and consistent change of heterotrophic bacterial communities in the four sediments.

\section{MATERIALS \& METHODS}

\subsection{Collection of sediments}

We selected sediments from four heterotrophic wetlands in the East of Lyon (France) that were expected to be colonized by different microbial communities due to their contrasted surroundings/watersheds (Table 1). After collection and travel back to the laboratory, the four sediments were sieved on net with a mesh size of $1 \mathrm{~mm}$ to eliminate coarse particles and benthic macrofauna, and for sediment homogenization. The volumetric grain size distribution of the 
four sediments were measured by laser diffractometry (Malvern Mastersizer 2000G). This analysis showed contrasted distribution peaks among sediments: SED1 was the finer sediment followed by SED4, SED2 and SED3 (Figure 1). Indeed, SED1 was characterized by 77\% of particles that could be ingested by Limnodrilus hoffmeisteri (particles $<184 \mu \mathrm{m}$, according to Juget, 1979) whereas only $62 \%$ of particles could be ingestible by worms in SED3. Analyses of total organic carbon (TOC) concentrations in the four sediments performed at the start of the experiment by elemental analysis (see the procedure below in paragraph 2.5 . on sediment chemical analyses). TOC concentrations showed that the four wetlands received high quantity of allochtonous organic matter from their watersheds with mean percentages $( \pm$ standard deviation) of TOC per sediment dry mass of $8.9 \pm 0.6 \%, 12.4 \pm 0.09,8.12 \pm 1.0 \%$ and $12.0 \pm$ $0.15 \%$ for SED1, SED2, SED3 and SED4, respectively. As a main determinant of benthic microbial respiration rates (e.g., Fuss and Smock, 1996), the high TOC concentrations measured in the four sediments underlined a dominance of heterotrophic processes in the four wetland sediments.

\subsection{Experimental setup}

The experiment was carried out in microcosms consisting of $1 \mathrm{~L}$ glass beakers (internal diameter: $10.5 \mathrm{~cm}$, height: $14 \mathrm{~cm}$ ) filled with a $5-\mathrm{cm}$ thick layer of sediment overlaid by $7 \mathrm{~cm}$ of synthetic water $\left(96 \mathrm{mg} . \mathrm{L}^{-1} \mathrm{NaHCO}_{3}, 39.4 \mathrm{mg} . \mathrm{L}^{-1} \mathrm{CaSO}_{4} \cdot 2 \mathrm{H}_{2} \mathrm{O}, 60 \mathrm{mg} . \mathrm{L}^{-1} \mathrm{MgSO}_{4} \cdot 7 \mathrm{H}_{2} \mathrm{O}\right.$, 4 mg. $\mathrm{L}^{-1} \mathrm{KCl}, \mathrm{pH}=7.5$ : US EPA, 1991) saturated with dissolved oxygen by bubbling with air the upper part of the water column. A total of 24 beakers were used to test the four sediments (SED1, SED2, SED3, and SED4), with 6 beakers per sediment. After preparation, beakers were maintained in the dark at $15{ }^{\circ} \mathrm{C}$ during 10 days before worm introduction. After this time of stabilization and before worm introduction, chemical measurements were performed to ensure that $\mathrm{CO}_{2}$ and nutrient $\left(\mathrm{NH}_{4}{ }^{+}, \mathrm{NO}_{3}{ }^{-}\right.$and $\left.\mathrm{PO}_{4}{ }^{3-}\right)$ release rates from the sediment were comparable for the 6 beakers assigned to each sediment. Then, two treatments were applied per tested sediment with three replicated beakers per sediment treatment: (1) without invertebrates (control) and (2) with 240 tubificid worms (tubificid treatment). Tubificid worms used in the experimental systems were obtained from a commercial breeder (Grebil, France) and were predominantly specimens of the species Limnodrilus hoffmeisteri (95\% in worm abundance, Creuzé des Châtelliers, comm. pers.). These worms were acclimated to experimental conditions $\left(15^{\circ} \mathrm{C}\right.$, sediment with a comparable grain size distribution and organic matter content than sediments used for the experiment) during 15 days. The tested density of 28,000 individuals per $\mathrm{m}^{2}$ fitted with typical natural densities (McCall and Fisher, 1980). 
Once introduced into the columns, worms dug rapidly into the sediment $(<2 \mathrm{~h})$. Experiments were conducted at $15{ }^{\circ} \mathrm{C}$ over 6 months, in the dark. Dark conditions were maintained during the whole duration of the experiment to prevent green algal growth in the water column of beakers. Indeed, occurrence of algal bloom in microcosms would make the interactions between worm activities and heterotrophic bacteria more complex to evaluate. Every 3-4 days, $1 / 3$ of the volume of overlying water was renewed with synthetic water in each beaker. After 6 months of experiment, $\mathrm{CO}_{2}$ and nutrient fluxes at the water-sediment interface were quantified in each beaker to evaluate the role of worms on these processes. During microcosm dismantling (month 6), sediment samples were also collected at depths of 0-1 cm (surface sediment layer) and 4-5 cm (deep sediment layer) with a cut-off syringe in each beaker for the measurement of total organic carbon, total nitrogen, total phosphorus and for the description of bacterial community structures. All sediment samples were frozen at $-80^{\circ} \mathrm{C}$. Tubificid worms were also recovered from sediments in all beakers to evaluate survival rates in the 4 sediments. These survival rates were high and comparable among the four sediment treatments with survival percentages $>95 \%$.

\section{3. $\mathrm{CO}_{2}$ fluxes at the water-sediment interface}

For all beakers, $\mathrm{CO}_{2}$ effluxes were determined at the laboratory during incubations of $30 \mathrm{~min}$ using a Plexiglas chamber (14.5 cm internal diameter and $18 \mathrm{~cm}$ long) and a flow-through technique using an ultra-portable greenhouse gas analyzer (Los Gatos Research, Mountain View, U.S.A.). Each beaker was placed in the Plexiglas chamber previously filled with $\mathrm{N}_{2}$ and sealed with a lid containing two ports connected to a peristaltic pump and to the greenhouse gas analyzer via gas-tight nylon tubing. The pump pulled ambient air into the airspace of the chamber at a rate of $800 \mathrm{~mL} \cdot \mathrm{min}^{-1}$ (equivalent to a turnover time of $3 \mathrm{~min}$ ) and out through the gas analyzer. $\mathrm{CO}_{2}$ efflux rates were calculated for each beaker as the increased concentrations during incubations of $30 \mathrm{~min}$ in the dark at $15^{\circ} \mathrm{C}$. They were expressed in $\mu \mathrm{mol}$ of $\mathrm{CO}_{2} \cdot \mathrm{s}^{-1} \cdot \mathrm{m}^{-}$

${ }^{2}$. Measured efflux rates were considered as proxies of organic matter mineralization occurring in beakers, allowing a comparison of degradation processes among treatments.

\subsection{Nutrient fluxes at the water-sediment interface}

After 6 months of experiment, 1/2 of the volume of overlying water was replaced with synthetic water. Then, in each beaker, water samples $(50 \mathrm{ml})$ were collected every hour during $6 \mathrm{~h}$ to measure nutrient fluxes at the water-sediment interface. Water samples were taken using acidwashed $100 \mathrm{ml}$ syringes and filtered through Whatman $\mathrm{GF} / \mathrm{F}$ filters $(0.7 \mu \mathrm{m})$. Concentrations 
of $\mathrm{NH}_{4}{ }^{+}, \mathrm{NO}_{2}{ }^{-}+\mathrm{NO}_{3}{ }^{-}$(hereafter referred to as $\mathrm{NO}_{3}{ }^{-}$considering the very low concentrations of $\mathrm{NO}_{2}{ }^{-}$), and $\mathrm{PO}_{4}{ }^{3-}$ in water were measured within $24 \mathrm{~h}$ of sample collection by colorimetric methods using a sequential analyzer (EASYCHEM 200, AMS, Frepillon, France). The release rates of $\mathrm{NH}_{4}{ }^{+}, \mathrm{NO}_{3}{ }^{-}$and $\mathrm{PO}_{4}{ }^{3-}$ across the sediment-water interface was calculated from changes over time in the concentration of each chemical species in the water column. The release rates were expressed as $\mu \mathrm{g} \cdot \mathrm{h}^{-1} \cdot \mathrm{m}^{-2}$ of water-sediment interface.

\subsection{Sediment chemical analyses}

Total organic carbon and total nitrogen content of sediment samples were determined by hightemperature combustion of in situ pre-acidified dry samples $\left(60^{\circ} \mathrm{C}, 48 \mathrm{~h}\right)$ and subsequent measurement of $\mathrm{CO}_{2}$ and $\mathrm{N}_{2}$ by thermal conductometry using an elemental analyzer (FlashEA, Thermo Electron Corporation). Total phosphorus content of sediment samples was determined by the method of Murphy and Riley (1962) after acid $\left(\mathrm{H}_{2} \mathrm{SO}_{4}\right)$ mineralization with persulfate at high temperature $\left(120^{\circ} \mathrm{C}\right)$.

\subsection{Bacterial community structures (16S metabarcoding)}

For each sample, DNA was extracted from $0.25 \mathrm{~g}$ of sediment using the PowerSoil DNA Isolation kit (MoBio Laboratories), according to the manufacturer's instructions. The V4-V5 hypervariable regions of the $16 \mathrm{~S}$ gene were amplified using a primer pair producing a $410 \mathrm{bp}$ amplicon $\quad$ (515f-C: 5'-GTGCCAGCMGCCGCGGTAA, $\quad 926 \mathrm{r}: \quad$ 5'CCGYCAATTYMTTTRAGTTT; Parada et al. 2016; Caporaso et al. 2012; Quince et al. 2011). A first PCR (PCR1) was performed in a $25 \mu \mathrm{l}$ reaction volume, using KAPA HiFI HotStart ReadyMix (containing 0.5 U of KAPA HiFi HotStart DNA Polymerase), $1 \mu$ l of DNA template, $0.24 \mu \mathrm{M}$ reverse and forward primers, $0.20 \mathrm{mg} / \mathrm{ml} \mathrm{BSA}$, and nuclease free $\mathrm{H}_{2} \mathrm{O}$. Thermal cycles were as follows: $95^{\circ} \mathrm{C}$ for $3 \mathrm{~min}\left(95^{\circ} \mathrm{C}\right.$ for $30 \mathrm{~s}, 55^{\circ} \mathrm{C}$ for $30 \mathrm{~s}, 72^{\circ} \mathrm{C}$ for $\left.1 \mathrm{~min}\right) 25$ times, and $72^{\circ} \mathrm{C}$ for $5 \mathrm{~min}$. The PCR was replicated three times for the 48 samples ( 4 sediments $* 2$ worm treatments $* 2$ sediment depth layers $* 3$ replicated beakers) and 2 controls (extraction and PCR controls). Amplification replicates were then pooled and purified using Agencourt AMPure XP beads. A second PCR (using PCR1 as DNA template) with 8 cycles was performed for sample indexing (indexes+P5/P7). PCR2 products were also purified with AMPure beads. Then, DNA was quantified using the Quantifluor dsDNA kit (ThermoFisher). All samples were pooled in equimolar proportions, and sequenced on an Illumina MiSeq platform with 5\% PhiX (Flow Cell V3, Paired-End $2 * 300$ bp) by Biofidal (Vaulx-en-Velin, France). 
Read number per sample varied from 130,236 to 293,612 with average 175,208 (median $168,766)$ reads per sample, except for PCR (547 reads) and extraction (9,103 reads) controls. Reads were processed with DADA2 R package (Callahan et al., 2016a, 2017), following the workflow described in Callahan et al. (2016b). In addition to demultiplexing and primer removal, R1 reads were trimmed at $270 \mathrm{bp}$ and $\mathrm{R} 2$ reads at $160 \mathrm{bp}$ (according to quality profiles). To account for variable sequencing depth, we performed an abundance normalization by subsampling each sample to 90000 sequences (i.e. the minimum number of sequences per sample after the filtering steps). We used the DADA2 method to infer Amplicon Sequence Variants (ASV), which does not rely on arbitrary threshold, and resolves variants that differ by as little as one nucleotide. Number of inferred ASV ranged from 1,658 to 5,557 unique sequences per sample (average 3,136). Taxonomy assignment of ASV was performed using the Silva database v128 (Pruesse et al., 2007; Quast et al., 2013). Eukaryotic sequences were filtered out based on this taxonomic assignment. The ASV abundance tables and taxonomic assignments produced at this stage were then analyzed using functions from the phyloseq $\mathrm{R}$ package (McMurdie and Holmes, 2014) to calculate alpha (ASV richness, Shannon index) and beta (Bray-curtis distances) diversity indices. Phylogeny-informed diversity indices were also computed: Faith's Phylogenetic Diversity (alpha diversity; PD function from the R package Picante; Faith, 1992; Kembel et al., 2010) and weighted Unifrac distances (beta diversity; Lozupone et al., 2011). Sequences of all ASV were aligned and cleaned using the AlignSeqs() function from the DECIPHER R package (with default parameters; Wright 2015, 2016) and trimAl to remove all positions in the alignment with gaps in $99 \%$ or more of the sequences ("gt 0.01", Capella-Gutiérrez et al., 2009). Final alignment length was 393bp. Then the phylogenetic tree of all ASV was inferred by first constructing a neighbor-joining tree, and then fitting a GTR+G+I (Generalized Time-Reversible with Gamma rate variation) maximum likelihood tree using the neighbor-joining tree as a starting point (phangorn R package; Schliep 2011).

\subsection{Statistical analyses}

Concentrations of total organic carbon, total nitrogen and total phosphorus in sediments were compared among sediment types, depths (surface and deep layers) and worm treatments using 3-way analyses of variance (ANOVA 3). The same statistical analysis was performed on ratios between total organic carbon and total nitrogen that were used as indicators of organic matter biodegradability in sediments (e.g., Meyers and Teranes, 2001; Sampei and Matsumoto, 2001). Fluxes of $\mathrm{CO}_{2}, \mathrm{NH}_{4}{ }^{+}, \mathrm{NO}_{3}{ }^{-}$and $\mathrm{PO}_{4}{ }^{3-}$ measured at the water-sediment interface in 
microcosms were compared among sediment types and worm treatments using 2-way ANOVA. For all variables, the normality and the homoscedasticity of the residues were tested using the Shapiro-Wilk's test and the Levene's test, respectively. When these assumptions were not met, data were transformed in ranks before statistical analyses using 2-way ANOVA.

The influence of sediment type, depth, and tubificid worms on sedimentary bacterial community structure was visualized using a double centered correspondence analysis (CA) performed with data on ASV abundances obtained from microcosms. Differences in bacterial community structures among sediment depth, sediment type and worm treatments were tested using permutational multivariate analyses of variance (PERMANOVA; Anderson 2001). Statistical tests were based on 1000 permutations of the Bray-Curtis matrix. To more specifically focus on the influence of tubificid worms on the bacterial communities, the dissimilarity (Bray-Curtis distance) of bacterial community structures between microcosms with worms and microcosms without worms was also calculated for each sediment type and sediment depth $(\mathrm{n}=9$ calculated pairwise dissimilarities between 3 microcosms with and 3 microcosms without worms). These dissimilarities associated with worm addition (hereafter referred to as "between" dissimilarities) were compared with dissimilarities calculated between the three replicated microcosms (for each sediment type and sediment depth: 3 replicated microcosms with worms, and 3 replicated microcosms without worms, for a total of 6 calculated pairwise dissimilarities, hereafter "within" dissimilarities). This comparison aimed at determining whether addition of tubificid worms significantly changed bacterial communities in each sediment type and depth. In such case, "between" dissimilarities are expected to be significantly higher than "within" dissimilarities. For each sediment depth, the significance of bacterial community structure changes associated with sediment type and worm treatments were tested using a 2-way ANOVA after a logit-transformation of data to meet normality assumptions. The same analysis was also performed using Unifrac distances (accounting for phylogenetic relationships between ASV).

The influences of depth, sediment and worm treatments on bacterial community diversity indices (ASV richness, Shannon diversity and Phylogenetic Diversity) were tested using non-parametric Wilcoxon and Kruskal-Wallis tests.

To explore the covariance between biogeochemical processes and bacterial community structures, we performed a coinertia analysis between the table of bacterial community structure (ASV abundances), and the table of element concentrations and nutrient fluxes, using the $\mathrm{R}$ package ade4 (Dray et al., 2007). This analysis measured the match between a correspondence analysis (CA) of ASV abundance data, and Principal Component Analysis 
(PCA) of biogeochemical data. This multi-table analysis was performed to examine the links between the two tables, each table using the same 48 samples as rows. The relationship between each pair of data sets was measured using the Rv-coefficient (vectorial correlation coefficient; Robert and Escoufier 1976). The $R v$-coefficient between two tables ranges between 0 and 1 and is a multidimensional equivalent of the ordinary correlation coefficient between two variables. For two given data sets $\mathrm{X}_{\mathrm{k}}$ and $\mathrm{X}_{\mathrm{l}}$, the $R v$-coefficient writes as follows:

$$
R v\left(X_{k}, X_{l}\right)=\frac{\operatorname{Covv}\left(X_{k}, X_{l}\right)}{\sqrt{\operatorname{Vav}\left(X_{k}\right) \sqrt{\operatorname{Vav}\left(X_{l}\right)}}}
$$

with $\operatorname{Covv}\left(X_{k}, X_{l}\right)=\operatorname{Trace}\left(X_{k}^{t} D_{n} X_{l} D_{p}\right.$ as the vectorial covariance and $\operatorname{Vav}(X \mid k)=\operatorname{Trace}$ $\left(X_{k}^{t} D_{n} X_{k} D_{p}\right)$ and $\operatorname{Vav}(X \mid l)=\operatorname{Trace}\left(X_{l}^{t} D_{n} X_{l} D_{q}\right)$ as the vectorial variance for $X_{k}$ and $X_{l}$, respectively; Matrix $D_{n}$ contains row weights (common to both data sets) and matrices $D_{p}$ and $D_{q}$ contain the column weights of $X_{k}$ and $X_{1}$, respectively (Blanc et al., 1998). To test the significance of $R v$-coefficients, rows were randomly permutated within tables. Permutations were repeated 1,000 times to obtain a null distribution of $R v$-coefficients. We assessed for statistical significance by determining the proportion of null values that were greater than the observed $R v$-coefficients.

\section{$\underline{\text { RESULTS }}$}

Influence of tubificid worms on organic matter processing and biogeochemical processes

The presence of tubificid worms significantly reduced the concentrations of total organic carbon and total nitrogen in the two depth layers of the four sediments (ANOVA 3, worm effect, $F_{(1,32)}=20.5, p<0.0001$ for TOC and $F_{(1,32)}=8.6, p<0.01$ for $\left.T N\right)$ at the unique exception of the surface layer of SED3 (Figure 2). This worm effect was not influenced by sediment type (ANOVA 3, "worm*sediment" effect, $\mathrm{F}_{(3,32)}=1.0, \mathrm{p}=0.38$ for $\mathrm{TOC}$ and $\mathrm{F}_{(3,32)}=0.4, \mathrm{p}=0.76$ for $\mathrm{TN}$ ) despite significant differences in concentrations of total organic carbon (TOC) and total nitrogen (TN) among the four sediments (Figure 2, ANOVA 3, sediment effect, $\mathrm{F}_{(1,32)}=278$, $\mathrm{p}<0.0001$ for $\mathrm{TOC}$ and $\mathrm{F}_{(1,32)}=41.3, \mathrm{p}<0.0001$ for $\left.\mathrm{TN}\right)$. Differences detected between sediment layers were mainly associated with SED3 showing around 3-fold higher TOC and TN concentrations in the top sediment layer than in depth (Figure 2).

In link with $\mathrm{TOC}$ and $\mathrm{TN}$ changes associated to worm activities, TOC/TN ratios were significantly higher in sediments with worms than in sediments without worms (ANOVA 3, worm effect, $\left.F_{(1,32)}=18.3, p<0.001\right)$ in the 4 sediments despite their contrasted TOC/TN ratios (ANOVA 3, sediment effect, $\mathrm{F}_{(1,32)}=157, \mathrm{p}<0.0001$ ). More precisely, the presence of worms 
increased mean TOC/TN ratios in from 10.75 to 11.72 in SED1, from 18.13 to 19.49 in SED2, from 15.47 to 17.47 in SED3, and from 18.09 to 18.63 in SED4. In contrast with TOC, TN and TOC/TN ratio, the influence of worms on the total phosphorus (TP) concentrations was not consistent among the four sediment types (ANOVA 3, "worm*sediment" effect, $F_{(3,32)}=6.9$, $\mathrm{p}<0.01$ ) and sediment depth (ANOVA 3, “worm*depth" effect, $F_{(3,32)}=109, \mathrm{p}<0.0001$ ). For example, tubificid worms increased TP concentration in the top layer of SED3 and produced the opposite effect in depth (Figure 2). It is also worth noting that TP concentrations widely varied among sediments with values from ca. $0.025 \%$ of dry sediment in SED1 to $0.105 \%$ in SED2 (ANOVA 3, sediment effect, $\mathrm{F}_{(3,32)}=568, \mathrm{p}<0.0001$ ).

Worm activities stimulated the release of $\mathrm{CO}_{2}$ from microcosms and $\mathrm{NH}_{4}{ }^{+}$fluxes at the water -sediment interface (ANOVA 2 on ranks, worm effect, $\mathrm{F}_{(1,16)}=59.3$ and $\mathrm{p}<0.0001$ for $\mathrm{CO}_{2}$ fluxes, and $\mathrm{F}_{(1,16)}=29.4$ and $\mathrm{p}<0.0001$ for $\mathrm{NH}_{4}{ }^{+}$fluxes) whatever the tested sediment (ANOVAs 2 on ranks, "sediment*worm" effect, $\mathrm{F}_{(3,16)}<2.3$, $\mathrm{p}>0.05$ for the two fluxes). These worm effects were consistent for the 4 tested sediments although $\mathrm{CO}_{2}$ and $\mathrm{NH} 4+$ fluxes were significantly different among sediments (ANOVA 2 on ranks, sediment effect, $F_{(3,16)}=4.9$ and $p<0.05$ for $\mathrm{CO}_{2}$ fluxes, and $\mathrm{F}_{(3,16)}=14.3$ and $\mathrm{p}<0.0001$ for $\mathrm{NH}_{4}{ }^{+}$fluxes for the two fluxes). For example, $\mathrm{NH}_{4}{ }^{+}$influxes (i.e. consumption of $\mathrm{NH}_{4}{ }^{+}$during incubation) were measured in SED1 whereas $\mathrm{NH}_{4}{ }^{+}$was released from sediment to water column $\left(\mathrm{NH}_{4}{ }^{+}\right.$efflux) in SED4 (Figure 3). $\mathrm{NO}_{3}{ }^{-}$and $\mathrm{PO}_{4}{ }^{3-}$ fluxes were also stimulated by tubificid worms (Figure 3, ANOVA 2, worm effect, $\mathrm{F}_{(1,16)}=36.1, \mathrm{p}<0.0001$ for $\mathrm{NO}_{3}{ }^{-}$fluxes and $\mathrm{F}_{(1,16)}=109, \mathrm{p}<0.0001$ for $\mathrm{PO}_{4}{ }^{3-}$ fluxes) but this worm effect depended on sediment type (ANOVA 2, "worm*sediment" effect, $F_{(3,16)}=16.7$, p $<0.0001$ for $\mathrm{NO}_{3}{ }^{-}$fluxes and $\mathrm{F}_{(3,16)}=66.4, \mathrm{p}<0.0001$ for $\mathrm{PO}_{4}{ }^{3-}$ fluxes). More precisely, stimulations of $\mathrm{NO}_{3}{ }^{-}$and $\mathrm{PO}_{4}{ }^{3-}$ fluxes by tubificid worms were mainly observed in SED2 and SED3 (Figure 3).

\section{Influence of worms on bacterial community structures in sediments}

The sequencing of the metabarcoding $16 \mathrm{~S}$ rRNA libraries yielded high-quality sequences distributed across 48 samples (4 sediments *2 worm conditions *2 sediment layers *3 replicates). After rarefaction-based abundance normalization (subsampling 90000 sequences per sample), Amplicon Sequence Variants (ASV) were inferred with the algorithm DADA2. A taxonomical identification was inferred (when possible) for each ASV, as well as an estimation of its abundance (i.e. proportion of sequences) in each sample, which was expected to represent its relative abundance in the corresponding community. 
Barplot representation (Figure 4) showed that the most abundant phyla were Planctomycetes, Bacteroidetes and Acidobacteria in all sediment types. However, Planctomycetes seemed to be largely dominant in SED1 and SED4, whereas the ratio between Planctomycetes and Bacteroidetes seemed to be more even in SED2, and to a lesser extent in SED3.

The first two axes of the correspondence analysis explained $24.4 \%$ of the variance in the bacterial community structure dataset. Based on these two axes, the correspondence analysis and PERMANOVA tests showed that differences in bacterial community structures among samples were mainly determined by sediment type (Figure 5, PERMANOVA, $\mathrm{F}_{(3,44)}=27.9$, $\mathrm{p}<0.0001)$. Although Figure 4 and Figure 5 did not indicate strong changes in bacterial community structures associated with worms, we detected a marginally significant effect of worm presence on bacterial community structure (PERMANOVA, $\mathrm{F}_{(1,46)}=2.0$, $\mathrm{p}=0.058$ ). In contrast, there was no significant influence of sediment depth on bacterial communities (PERMANOVA, $\mathrm{F}_{(1,46)}=1.6, \mathrm{p}>0.1$ ).

To determine whether changes of community structures could be detected at a finer scale, we measured the dissimilarity between bacterial communities (i.e. Bray-Curtis and Unifrac distances), in each depth layer independently. If the presence of bioturbating worms did not significantly change the bacterial community structures, the average dissimilarity between treatments (with vs. without bioturbation; referred to as "between" dissimilarities) would be comparable to the average dissimilarity between triplicates ("within" dissimilarities; see M\&M for a detailed explanation). Figures 6 and S1 (based on Bray-Curtis and Unifrac distances respectively) showed that for all sediment types and sediment layers, bacterial communities dissimilarity was always lower among triplicates (i.e. within a given condition) compared to the dissimilarity measured between experimental conditions (+/- worms). Two-way ANOVAs indicated that "between" dissimilarities were significantly higher than "within" dissimilarities in surface and deep layers of sediment (surface layer: $F_{(1,52)}=766$ and $p<0.0001$ for BrayCurtis distances, $F_{(1,52)}=779$ and $p<0.0001$ for Unifrac distances; deep layer: $F_{(1,52)}=165$ and $p$ $<0.0001$ for Bray-Curtis distances, $\mathrm{F}_{(1,52)}=138$ and $\mathrm{p}<0.0001$ for Unifrac distances).

These results indicated that bioturbation by tubificid worms was associated with changes in bacterial community structures. Although these community changes were not influenced by sediment type in the deeper layer of sediments (ANOVAs 2, "worm*sediment" interaction, $F_{(3,52)}=1.0$ and $p>0.2$ for Bray-Curtis distances, $F_{(3,52)}=1.5$ and $p>0.4$ for Unifrac distances), this effect was not consistent across the four tested sediments in surface layer (ANOVAs 2, "worm*sediment" interaction, $\mathrm{F}_{(3,52)}=48.5$ and $\mathrm{p}<0.0001$ for Bray-Curtis distances, $\mathrm{F}_{(3,52)}=14.6$ and $\mathrm{p}<0.0001$ for Unifrac distances). First, the CA representation (Figure 5) 
showed that the presence of worms did not induce convergent bacterial community changes (i.e. in the same direction) in the four sediments. For example, tubificid worms tended to modify bacterial community structure in the surface layer of SED1 by influencing ASV groups contributing to the horizontal axis of the CA whereas the influence of worms on bacterial community structure in the surface layer of SED3 tended to modify ASV groups contributing the vertical axis of the CA (Figure 5). Second, statistical analysis of the count matrix (ASV abundances) using DESeq2 (Love et al., 2014) did not support any systematic change due to the presence of worms in all sediment types (see details in the Supplementary Material 1).

\section{Influence of worms on bacterial diversity in sediments}

Based on alpha diversity estimates (Richness, Shannon index and Phylogenetic Diversity), a reduced bacterial diversity was measured in presence of worms (Figure 7; Wilcoxon tests, worm effect, $\mathrm{p}<0.005$ for the three alpha diversity indices) despite large differences in bacterial diversity among the 4 tested sediments (Kruskal-Wallis tests, sediment effect, $\mathrm{p}<$ 0.001 for the three alpha diversity indices). In contrast, sediment depth did not have any influence on bacterial diversity (Wilcoxon tests, depth effect, $p>0.15$ for the three diversity indices).

\section{Links between the influences of tubificid worms on biogeochemical processes and bacterial} community structures

A co-inertia analysis has been performed to evaluate the co-variation between biogeochemical processes and bacterial community structure datasets. The structure shared by the two datasets was not significantly different from a structure expected from random association $(R v$ coefficient $=0.26, p>0.05)$, indicating a lack of significant co-variation between the table of bacterial communities and the table of nutrient fluxes $\left(\mathrm{CO}_{2}, \mathrm{NH}_{4}{ }^{+}, \mathrm{NO}_{3}{ }^{-}, \mathrm{PO}_{4}{ }^{3-}\right)$.

\section{$\underline{\text { DISCUSSION }}$}

As reported in the literature (Svensson et al., 2001; Hölker et al., 2015; Baranov et al., 2016), tubificid worms stimulated both $\mathrm{CO}_{2}$ and nutrient fluxes at the water-sediment interface for the four sediment types. Stimulations of $\mathrm{CO}_{2}$ fluxes by worms $(+50 \%$ to $+400 \%)$ were comparable to those reported by Pigneret et al. (2016) in short-term experiments lasting one month. The influence of worms on nutrient fluxes was also consistent with data reported from the literature showing increased fluxes of inorganic dissolved nitrogen $\left(\mathrm{NH}_{4}{ }^{+}\right.$and $\left.\mathrm{NO}_{3}{ }^{-}\right)$from sediments to 
overlying water in the presence of bioturbating invertebrates (Svensson et al., 2001; Michaud et al., 2006; Gautreau et al., 2020). These stimulations of fluxes by tubificid worms cannot be explained by worm excretion and respiration rates. Indeed, by assuming that 1 mole of $\mathrm{O}_{2}$ consumed produces 1 mole of $\mathrm{CO}_{2}$ during respiration, the $\mathrm{O}_{2}$ consumption of Limnodrilus hoffmeisteri measured by Lou et al. (2013) at $15^{\circ} \mathrm{C}$ (temperature of the present experiment) in freshwater suggests that the sole respiration of the 240 worms introduced in our mesocosms would be responsible of a flux of around $0.003 \mu \mathrm{mol}$ of $\mathrm{CO}_{2} \cdot \mathrm{s}^{-1} \cdot \mathrm{m}^{-2}$, a flux rate which is at least 3 -fold lower than the stimulation of $\mathrm{CO}_{2}$ flux induced by worms in our sediments (Figure 3 ). Thus, positive effects of worms on nutrient and $\mathrm{CO}_{2}$ fluxes were predominantly due to a stimulation of microbial activities involved in organic matter mineralization. By creating dense gallery networks, worms increased the exchanges at the water-sediment interface, increasing microbial activities involved in nutrient cycling and organic matter processing in mesocosms. Interestingly, working on a period of several months, which is longer than experiments usually performed with bioturbating fauna, allowed us to quantify a significant reduction of total organic carbon and nitrogen contents in sediments in presence of worms. Similarly, Shen et al. (2017) observed the same effects of two bioturbation species (the clam Meretrix meretrix and polychaete Perinereis aibuhitensis) on sedimentary organic matter during a field experiment of 2-3 months in sandy intertidal flats. The observed changes in organic matter content in sediments, which are consistent with $\mathrm{CO}_{2}$ fluxes (reflecting organic matter mineralization), illustrate the major role played by tubificid worms in organic matter processing.

Although biogeochemical processes were largely mediated by worm bioturbation, bacterial communities were mainly structured by sediment type (Figure 5). Indeed, differences in sediment grain sizes (Figure 1), total organic carbon, total nitrogen and phosphorus contents (Figure 2) likely have shaped contrasting habitats for microorganisms. As a matter of fact, a myriad of microbial studies (Findlay et al., 2003; Johnson et al., 2012; Battin et al., 2016; Smith et al., 2018; Avila et al., 2019) demonstrated that habitat heterogeneity and especially organic matter availability play a key role in structuring microbial communities. In these conditions, environmental changes induced by worms were not strong enough to outweigh the structuring effect associated with sediment types. Despite this result, we observed a marginally significant effect of worms on bacterial community structures on the whole dataset, which was significantly strengthened when considering each sediment independently. Indeed, dissimilarities in community structures were higher between worm and control treatments than among replicated control mesocosms and among replicated worm mesocosms, illustrating a 
significant influence of worms on bacterial community structures for each sediment and sampled depth layer. However, these changes were not consistent among sediments for the top sediment layer as the presence of worms did not impact the same bacterial groups in the four sediments. These observations suggest that worm-bacteria interactions were mainly driven by initial bacterial community structures. More precisely, worm activities did not stimulate or reduce the abundances of the same bacterial groups in the four sediments because these sediments were colonized bycontrasted bacterial communities (as observed in Figure 5).

Despite the fact that worm-bacteria interactions largely depended on tested sediment, we demonstrated for the first time that tubificid worms consistently reduced bacterial diversity at sediment surface but also in deep layers of sediments. The reduced diversity of bacteria at the sediment surface was consistent with our hypothesis stating that fecal pellets egested at the surface by worms were impoverished in bacteria after passage through the digestive tract as observed in tubificid worms (Wavre and Brinkhurst, 1971) and in earthworms (Schönholzer et al., 2002; Gómez-Brandón et al., 2012; Aira et al., 2016). Reduced diversity in deeper sediment layers was more surprising as bioturbation was expected to diversify the biogeochemical conditions in sediments and thus the ecological niches available for bacteria (Laverlock et al., 2010). The reduced bacterial diversity on the whole sedimentary column due to tubificid worms could be associated with the impoverishment in organic matter measured in sediments bioturbated by worms. Indeed, Deng et al. (2020) recently showed that the availability of fresh organic matter had a significant control on bacterial community structures in marine sediments. Thus, during the six months of the present experiments, tubificid worms most likely reduced the quality (consuming the most biodegradable fraction of organic matter) and the diversity of the organic matter in sediments by stimulating organic matter degradation (i.e., $\mathrm{CO}_{2}$ production and total organic carbon loss). Measurements of TOC/TN ratios in sediments supported this interpretation because the higher ratios measured in bioturbated than in non-bioturbated sediments indicated a lower biodegradability of organic matter in bioturbated sediments (Sampei and Matsumoto, 2001). Consequently, the availability and diversity of organic matter was more limiting in bioturbated than in non-bioturbated sediments, reducing the ability of multiple bacterial taxa to coexist (increased competition with the reduction of trophic niches, Wilson and Lindow, 1994; Langenheder et al., 2010; Simek et al., 2014; Pernthaler, 2017). Indeed, the positive relationship between the diversity of organic molecules and bacterial diversity has been already demonstrated in several environments (Sarmento and Gasol, 2012; Teeling et al., 2012; Landa et al., 2013; Li et al., 2018; Zhao et al., 2019; Liu et al., 2019; 
Muscarella et al., 2019). Therefore, our results suggest that the enhancement of organic matter processing and nutrient cycling by worm bioturbation reduces the number of trophic niches available on the sedimentary column, decreasing bacterial diversity. It is worth noting that these results obtained in experimental conditions are not necessarily applicable to the wetland ecosystems which are characterized by regular supplies of organic matter or significant autotrophic productivity that would fuel the sedimentary compartment with fresh organic matter. Considering these two aspects (organic matter supply and/or autotrophic activity) in future works would add more field-relevant processes in our experiment approach. For example, allowing the development of phototrophic organisms at the water-sediment interface of our microcosms would probably change the vertical distributions of biogeochemical processes and microbial communities in the sediment (as observed in marine sediments by Deng et al., 2020), leading to more complex interactions between worms and micro-organisms than those observed in the present study.

Our last hypothesis stating that bioturbation-driven changes in bacterial communities were directly involved in the stimulation of biogeochemical processes was not validated by our results. Indeed, bioturbation activities produced significant stimulations of $\mathrm{CO}_{2}$ and nutrient fluxes but induced only slight changes of bacterial community structures. Besides, variations in bacterial community structure and variations in biogeochemical fluxes among sediment and worm treatments did not have a significant co-structure, indicating that the stimulation of biogeochemical processes was not mediated by specific modifications of bacterial communities by worms. Thus, worm bioturbation more likely stimulated the activities of microorganisms initially present in each sediment. As the studied process of organic matter degradation is performed by a wide diversity of bacterial taxa (high functional redundancy, Risse-Buhl et al., 2017), it is not surprising that the significant stimulations of this microbial process by worms in the four sediments were not associated with a comparable change in bacterial community structure in the four sediments. Nevertheless, it could be different for more specific functions which are not shared by a large variety of bacteria (i.e. lower functional redundancy). To better understand the role played by bacteria in several biogeochemical processes, we tried to infer metabolic functions using FAPROTAX pipeline (Louca et al., 2016) by finding phylogenetic correspondences between our ASV dataset and bacterial genomic reference databases. This approach gave promising results by indicating a relative decrease $(-39 \%$ in average) in abundance of methanotroph bacteria in the surface layer of bioturbated mesocosms where worms rework and aerate sediments. Nevertheless, this kind of results was based on less than $19 \%$ of all ASV, because most of them were too phylogenetically distant from the bacteria 
species present in the reference databases to achieve any reliable metabolic inference. Therefore, evaluating the role of tubificid worms on bacterial functional groups involved in key elemental cycles (carbon, nitrogen and sulfur cycles in sediments would require further analyses such as metagenomics or qPCR approaches targeting specific functions (e.g., Dale et al., 2019b). This next step is fundamental to finely decipher the metabolic capacities of bacterial communities and their responses to abiotic and biotic environmental conditions.

\section{ACKNOWLEDGEMENTS}

The authors would like to thank Elie Robert (L3 Internship), Félix Vallier and Ludovic Guillard for their help during the lab experimentations and biogeochemical analyses. We are also grateful to Agnès Nguyen (Biofidal, Lyon) for support and advice.

\section{DATA AVAILABILITY}

The raw reads generated for this study have been deposited in the NCBI database under the BioProject accession number PRJNA722295.

\section{$\underline{\text { FUNDING }}$}

This work was supported by Agence Nationale de la Recherche [ANR-16-CE32-0006 FROG], the LEHNA laboratory (Thème transversal "Génomique Environnementale"), and Lyon Métropole and Agence de l'Eau Rhône-Méditerranée-Corse within the framework of the experimental observatory for urban hydrology (OTHU, http://www.graie.org/othu/) and Rhône Basin LTER (ZABR). The laboratory experiments were performed on the Sedaqua Platform (FR 3728 BioEnviS) supported by a Contrat Plan Etat Région 2015-2020 (Lyon Metropole / Auvergne-Rhône-Alpes Region / French Government). His work was also realized within the Graduate School H2O'Lyon [ANR-17-EURE-0018] and Université de Lyon (UdL), as part of the program "Investissements d'Avenir " run by Agence Nationale de la Recherche (ANR).

\section{$\underline{\text { REFERENCES }}$}

Aira, M., Olcina, J., Pérez-Losada, M., Domínguez, J., 2016. Characterization of the bacterial communities of casts from Eisenia andrei fed with different substrates. Appl. Soil Ecol. 98, 103-11. https://doi.org/10.1016/j.apsoil.2015.10.002 
Aller, R.C., 1983. The importance of the diffusive permeability of animal burrow linings in determining marine sediment chemistry. J. Mar. Res. 41, 299-322. https://doi.org/10.1357/002224083788520225

Anderson, M.J., 2001. A new method for non-parametric multivariate analysis of variance. Austral Ecol. 26, 32-46. https://doi.org/10.1111/j.1442-9993.2001.01070.pp.x

Anschutz, P., Ciutat, A., Lecroart, P., Gérino, M., Boudou, A., 2012. Effects of tubificid worm bioturbation on freshwater sediment biogeochemistry. Aquat. Geochem. 18, 475-97. https://doi.org/10.1007/s10498-012-9171-6

Ávila, M.P., Brandão, L.P., Brighenti, L.S., Tonetta, D., Reis, M.P., Stæhr, P.A., Asmala, E., Amado; A.M., Barbosa, F.A.R., Bezerra-Neto, J.F., Nascimento, A.M.A., 2019. Linking shifts in bacterial community with changes in dissolved organic matter pool in a tropical lake. Sci. Tot. Environ. 672, 990-1003. https://doi.org/10.1016/j.scitotenv.2019.04.033

Baranov, V., Lewandowski, J., Krause, S., 2016. Bioturbation enhances the aerobic respiration of lake sediments in warming lakes. Biol. Lett. 12, 8-11. https://doi.org/10.1098/rsbl.2016.0448

Battin, T.J., Besemer, K., Bengtsson, M.M., Romani, A.M., Packmann, A.I., 2016. The ecology and biogeochemistry of stream biofilms. Nature Rev. Microbiol. 14, 251. https://doi.org/10.1038/nrmicro.2016.15

Bertics, V.J., Ziebis, W., 2010. Bioturbation and the role of microniches for sulfate reduction in coastal marine sediments. Environ. Microbiol. 12, 3022-34. https://doi.org/10.1111/j.1462-2920.2010.02279.x

Blanc, L., Chessel, D., Dolédec, S., 1998. Étude de la stabilité temporelle des structures spatiales par analyses d'une série de tableaux de relevés faunistiques totalement appariés. Bull. Fr. Pêche Pisc. 348, 1-21. https://doi.org/10.1051/kmae:1998049

Callahan, B.J., McMurdie, P.J., Rosen, M.J., Han, A.W., Johnson, A.J.A., Holmes, S.P., $2016 a$. DADA2: high-resolution sample inference from Illumina amplicon data. Nature Meth. 13, 581. https://doi.org/10.1038/nmeth.3869

Callahan, B.J., Sankaran, K., Fukuyama, J.A., McMurdie, P.J., Holmes, S.P., 2016. Bioconductor workflow for microbiome data analysis: from raw reads to community analyses. F1000Research, 5. https://doi.org/10.12688/f1000research.8986.2 
Callahan, B.J., McMurdie, P.J., Holmes, S.P., 2017. Exact sequence variants should replace operational taxonomic units in marker-gene data analysis. ISME J. 11, 2639-43. https://doi.org/10.1038/ismej.2017.119

Capella-Gutiérrez, S., Silla-Martínez, J.M., Gabaldón, T., 2009. trimAl: A tool for automated alignment trimming in large-scale phylogenetic analyses. Bioinformatics 25, 1972-3. https://doi.org/10.1093/bioinformatics/btp348

Chatarpaul, L., Robinson, J.B., Kaushik, N.K., 1980. Effects of tubificid worms on denitrification and nitrification in stream sediment. Can. J. Fish. Aquat. Sci. 37, 656-63. https://doi.org/10.1139/f80-082

Ciutat, A., Weber, O., Gérino, M., Boudou, A., 2006. Stratigraphic effects of tubificids in freshwater sediments: a kinetic study based on X-ray images and grain-size analysis. Acta Oecol. 30, 228-37. https://doi.org/10.1016/j.actao.2006.04.004

Cuny, P., Miralles, G., Cornet-Barthaux, V., Acquaviva, M., Stora, G., Grossi, V., Gilbert, F., 2007. Influence of bioturbation by the polychaete Nereis diversicolor on the structure of bacterial communities in oil contaminated coastal sediments. Mar. Poll. Bull. 54, 452-59. https://doi.org/10.1016/j.marpolbul.2006.12.008

Dale, H., Taylor, J.D., Solan, M., Lam, P., Cunliffe, M., 2019a. Polychaete mucopolysaccharide alters sediment microbial diversity and stimulates ammoniaoxidising functional groups. FEMS Microbiol. Ecol. 95, fiy234. https://doi.org/10.1093/femsec/fiy234

Dale, H., Solan, M., Lam, P., Cunliffe, M., 2019b. Sediment microbial assemblage structure is modified by marine polychaete gut passage. FEMS Microbiol. Ecol. 95, fiz047. https://doi.org/10.1093/femsec/fiz047

Deng, L., Bölsterli, D., Kristensen, E., Meile, C., Su, C.C., Bernasconi, S.M., Seidenkrantz, M.S., Glombitza, C., Lagostina, L., Han, X., Jørgensen, B.B., Røy, H., Lever, M.A., 2020. Macrofaunal control of microbial community structure in continental margin sediments. Proc. Natl. Acad. Sci. USA, 117, 15911-15922. https://doi.org/10.1073/pnas.1917494117

Dray, S., Dufour, A.-B., Chessel, D. 2007. The ade4 package - II: Two-table and K-table methods. R News 7, 47-52. https://doc.uments.com/s-the-ade4-package-ii-two-table-andk-table-methods.pdf 
Faith, D.P., 1992. Conservation evaluation and phylogenetic diversity. Biol. Cons. 61, 1-10. https://doi.org/10.1016/0003-2697(75)90168-2

Fuss, C., Smock, L. 1996. Spatial and temporal variation of microbial respiration rates in a blackwater stream. Freshwat. Biol. 36, 339-349. https://doi.org/10.1046/j.13652427.1996.00095.x

Gautreau, E., Volatier, L., Nogaro, G., Gouze, E., Mermillod-Blondin, F., 2020. The influence of bioturbation and water column oxygenation on nutrient recycling in reservoir sediments. Hydrobiologia 847, 1027-40. https://doi.org/10.1007/s10750-019-04166-0

Findlay, S.E., Sinsabaugh, R.L., Sobczak, W.V., Hoostal, M., 2003. Metabolic and structural response of hyporheic microbial communities to variations in supply of dissolved organic matter. Limnol. Oceanogr. 48, 1608-1617. https://doi.org/10.4319/lo.2003.48.4.1608

Gómez-Brandón, M., Lores, M., Domínguez, J., 2012. Species-specific effects of epigeic earthworms on microbial community structure during first stages of decomposition of organic matter PLoS One 7, e31895. https://doi.org/10.1371/journal.pone.0031895

Hölker, F., Vanni, M.J., Kuiper, J.J., Meile, C., Grossart, H.P., Stief, P., Adrian, R., Lorke, A., Dellwig, O., Brand, A., Hupfer, M., Mooij, W.M., Nützmann, G., Lewandowski, J., 2015. Tube-dwelling invertebrates: Tiny ecosystem engineers have large effects in lake ecosystems. Ecol. Monog. 85, 333-51. https://doi.org/10.1890/14-1160.1

Hou, Y., Li, B., Feng, G., Zhang, C., He, J., Li, H., Zhu, J., 2021. Responses of bacterial communities and organic matter degradation in surface sediment to Macrobrachium nipponense bioturbation. Sci. Tot. Environ. 759, 143534. https://doi.org/10.1016/j.scitotenv.2020.143534

Huang, R., Zhao, D.Y., Zeng, J., Tian, M.Y., Shen, F., Jiang, C.-L., Huang, F., Yu, Z.-B., Wu, Q.L., 2016. Bioturbation of tubificid worms affects the abundance and community composition of ammonia-oxidizing archaea and bacteria in surface lake sediments. Annals Microbiol. 66, 1065-73. https://doi.org/10.1007/s13213-016-1192-8

Johnson, L.T., Royer, T.V., Edgerton, J.M., Leff, L.G., 2012. Manipulation of the dissolved organic carbon pool in an agricultural stream: responses in microbial community structure, denitrification, and assimilatory nitrogen uptake. Ecosystems 15, 1027-38. https://doi.org/10.1007/s10021-012-9563-x 
Kembel, S.W., Cowan, P.D., Helmus, M.R., Cornwell, W.K., Morlon, H., Ackerly, D.D., Blomberg, S.P., Webb, C.O. 2010. Picante: R tools for integrating phylogenies and ecology. Bioinformatics 26, 1463-64. https://doi.org/10.1093/bioinformatics/btq166

Krantzberg, G., 1985. The influence of bioturbation on physical, chemical and biological parameters in aquatic environments: a review. Environ. Poll. Ser. A 39, 99-122. https://doi.org/10.1016/0143-1471(85)90009-1

Kristensen, E., Penha-Lopes, G., Delefosse, M., Valdemarsen, T., Quintana, C. O., Banta, G. T., 2012. What is bioturbation? The need for a precise definition for fauna in aquatic sciences. Mar. Ecol. Prog. Ser. 446, 285-302. https://doi.org/10.3354/meps09506

Landa, M., Cottrell, M.T., Kirchman, D.L., Blain, S., Obernosterer, I., 2013. Changes in bacterial diversity in response to dissolved organic matter supply in a continuous culture experiment. Aquat. Microbiol. Ecol. 69, 157-68. https://www.intres.com/articles/ame2012/69/a069p157.pdf

Laverock B., Smith C.J., Tait K., Osborn, A.M., Widdicombe, S., Gilbert, J.A., 2010. Bioturbating shrimp alter the structure and diversity of bacterial communities in coastal marine sediments. ISME J. 4, 1531-1544. https://doi.org/10.1038/ismej.2010.86

Li, Y., Hua, X., Zheng, F., Dong, D., Liang, D., Guo, Z., 2016. Effects of tubificid bioturbation on pore structures in sediment and the migration of sediment particles. Env. Sci. Poll. Res. 23, 8064-8075. https://doi.org/10.1007/s11356-015-5949-6

Li, H.Y., Wang, H., Wang, H.T., Xin, P.Y., Xu, X.H., Ma, Y., Liu, W.P., Teng, C.Y., Jiang, C.L., Lou, L.P., Arnold, W., Cralle, L., Zhu, Y.G., Chu, J.F., Gilbert, J.A., Zhang, Z.J. 2018. The chemodiversity of paddy soil dissolved organic matter correlates with microbial community at continental scales. Microbiome 6, 1-16. https://doi.org/10.1186/s40168018-0561-X

Liu, S.J., Xi, B.D., Qiu, Z.P., He, X.S., Zhang, H., Dang, Q.L., Zhao, X.Y., Li, D., 2019. Succession and diversity of microbial communities in landfills with depths and ages and its association with dissolved organic matter and heavy metals. Sci. Tot. Environ. 651, 909-916. https://doi.org/10.1016/j.scitotenv.2018.09.267

Lou, J., Cao, Y., Sun, P., Zheng, P., 2013. The effects of operational conditions on the respiration rate of Tubificidae. PLoS One 8, e81219. https://doi:10.1371/journal.pone.0081219 
Love, M.I., Huber, W., Anders, S., 2014. Moderated estimation of fold change and dispersion for RNA-seq data with DESeq2. Genome Biology 15, 550. https://doi.org/10.1186/s13059-014-0550-8

Lozupone, C., Lladser, M. E., Knights, D., Stombaugh, J., Knight, R. 2011. UniFrac: An effective distance metric for microbial community comparison. ISME J. 5, 169-72. https://doi.org/10.1038/ismej.2010.133

Lukwambe, B., Yang, W., Zheng, Y., Nicholaus, R., Zhu, J., Zheng, Z., 2018. Bioturbation by the razor clam (Sinonovacula constricta) on the microbial community and enzymatic activities in the sediment of an ecological aquaculture wastewater treatment system. Sci. Tot. Environ. 643, 1098-1107. https://doi.org/10.1016/j.scitotenv.2018.06.251

Meyers, P.A., Teranes, J.L., 2001. Sediment organic matter. In: Last, W.M., Smol, J.P. (Eds.), Tracking environmental change using lake sediments: Physical and geochemical methods. Developments in paleoenvironmental research. Springer Netherlands, Dordrecht, pp. 239-269.

McCall, P.L., Fisher, J.B., 1980. Effects of tubificid oligochaetes on physical and chemical properties of Lake Erie sediments. In: Brinkhurst, R.O., Cook, D.G. (Eds.), Aquatic oligochaete biology. Springer, Boston, pp. 253-317.

McCall, P.L., Tevesz, M.J.S., 1982. The effects of benthos on physical properties of freshwater sediments. In: McCall, P.L., Tevesz, M.J.S. (Eds.), Animal-sediment relations. The biogenic alteration of sediments. Plenum Press, New York, pp. 105-176.

McMurdie, P.J., Holmes, S., 2014. Waste not, want not: why rarefying microbiome data is inadmissible. PLoS Comput. Biol. 10. https://doi.org/10.1371/journal.pcbi.1003531

Mermillod-Blondin, F., Nogaro, G., Vallier, F., Gibert, J., 2008. Laboratory study highlights the key influences of stormwater sediment thickness and bioturbation by tubificid worms on dynamics of nutrients and pollutants in stormwater retention systems. Chemosphere 72, 213-23. https://doi.org/10.1016/j.chemosphere.2008.01.052

Mermillod-Blondin, F., 2011. The functional significance of bioturbation and biodeposition on biogeochemical processes at the water-sediment interface in freshwater and marine ecosystems. J. North Am. Benthol. Soc. 30, 770-78. https://doi.org/10.1899/10-121.1

Mermillod-Blondin, F., Bouvarot, M., Déjollat, Y., Adrien, J., Maire, E., Lemoine, D., Marmonier, P., Volatier, L., 2018. Influence of tubificid worms on sediment structure, 
benthic biofilm and fauna in wetlands: A field enclosure experiment. Freshwat. Biol. 63, 1420-32. https://doi.org/10.1111/fwb.13169

Mermillod-Blondin, F., Gérino, M., Creuzé des Châtelliers, M., Degrange, V., 2002. Functional diversity among 3 detritivorous hyporheic invertebrates: An experimental study in microcosms. J. North Am. Benthol. Soc. 21, 132-49. https://doi.org/10.2307/1468305

Mermillod-Blondin, F., Lemoine, D.G., 2010. Ecosystem engineering by tubificid worms stimulates macrophyte growth in poorly oxygenated wetland sediments. Funct. Ecol. 24, 444-453. https://doi.org/10.1111/j.1365-2435.2009.01624.x

Michaud, E., Desrosiers, G., Mermillod-Blondin, F., Sundby, B., Stora, G., 2006. The functional group approach to bioturbation: II. The effects of the Macoma balthica community on fluxes of nutrients and dissolved organic carbon across the sediment-water interface. J. Exp. Mar. Biol. Ecol. 337, 178-89. https://doi.org/10.1016/j.jembe.2006.06.025

Murphy, J., Riley, J.P. 1962. A modified single solution method for the determination of phosphate in natural waters. Anal. Chim. Acta 27, 31-36. papers://d389027f-1c90-43ee8f36-77ce4678000f/Paper/p19

Muscarella, M.E., Boot, C.M., Broeckling, C.D., Lennon, J.T., 2019. Resource heterogeneity structures aquatic bacterial communities. ISME J. 13, 2183-2195. https://doi.org/10.1038/s41396-019-0427-7

Navel, S., Mermillod-Blondin, F., Montuelle, B., Chauvet, E., Marmonier, P., 2012. Sedimentary context controls the influence of ecosystem engineering by bioturbators on microbial processes in river sediments. Oikos 121, 1134-44. https://doi.org/10.1111/j.1600-0706.2011.19742.x

Navel, S., Mermillod-Blondin, F., Montuelle, B., Chauvet, E., Simon, L., Marmonier, P., 2011. Water-sediment exchanges control microbial processes associated with leaf litter degradation in the hyporheic zone: a microcosm study. Microb. Ecol. 61, 968-79. https://doi.org/10.1007/s00248-010-9774-7

Nogaro, G., Burgin, A.J. 2014. Influence of bioturbation on denitrification and dissimilatory nitrate reduction to ammonium (DNRA) in freshwater sediments. Biogeochemistry 120, 279-94. https://doi.org/10.1007/s10533-014-9995-9 
Papaspyrou, S., Gregersen, T., Cox, R.P., Thessalou-Legaki, M., Kristensen, E., 2005. Sediment properties and bacterial community in burrows of the ghost shrimp Pestarella tyrrhena (Decapoda: Thalassinidea). Aquat. Microb. Ecol. 38, 181-90. doi:10.3354/ame038181

Papaspyrou, S., Gregersen, T., Kristensen, E., Christensen, B., Cox, R.P., 2006. Microbial reaction rates and bacterial communities in sediment surrounding burrows of two nereidid polychaetes (Nereis diversicolor and $N$. virens). Mar. Biol. 148, 541-50. https://doi.org/10.1007/s00227-005-0105-3

Pernthaler, J. 2017. Competition and niche separation of pelagic bacteria in freshwater habitats. Environ. Microbiol. 19, 2133-50. https://doi.org/10.1111/1462-2920.13742

Pigneret, M., Mermillod-Blondin, F., Volatier, L., Romestaing, C., Maire, E., Adrien, J., Guillard, L., Roussel, D., Hervant, F., 2016. Urban pollution of sediments: Impact on the physiology and burrowing activity of tubificid worms and consequences on biogeochemical processes. Sci. Tot. Environ. 568, 196-207. https://doi.org/10.1016/j.scitotenv.2016.05.174

Pinheiro, J., Bates, D., DebRoy, S., Sarkar, D., R Core Team, 2021. nlme: Linear and Nonlinear Mixed Effects Models. R package version 3.1-152, https://CRAN.Rproject.org/package=nlme.

Pruesse, E., Quast, C., Knittel, K., Fuchs, B.M., Ludwig, W., Peplies, J., Glöckner, F.O. 2007. SILVA: A comprehensive online resource for quality checked and aligned ribosomal RNA sequence data compatible with ARB. Nucleic Acids Res. 35, 7188-96. https://doi.org/10.1093/nar/gkm864

Quast, C., Pruesse, E., Yilmaz, P., Gerken, J., Schweer, T., Yarza, P., Peplies, J., Glöckner, F.O., 2012. The SILVA ribosomal RNA gene database project: improved data processing and web-based tools. Nucleic Acids Res. 41(D1), D590-D596. https://doi.org/10.1093/nar/gks1219

Sarmento, H., Gasol, J.M., 2012. Use of phytoplankton-derived dissolved organic carbon by different types of bacterioplankton. Environ. Microbiol. 14, 2348-60. https://doi.org/10.1111/j.1462-2920.2012.02787.x 
Sampei, Y., Matsumoto, E., 2001. C/N ratios in a sediment core from Nakaumi Lagoon, southwest Japan. Usefulness as an organic source indicator. Geochem. J. 35, 189-205. https://doi.org/10.2343/geochemj.35.189

Robert, P., Escoufier, Y. 1976. A unifying tool for linear multivariate statistical methods: the RV-coefficient. Appl. Stat. 25, 257-265. https://doi.org/10.2307/2347233

Schliep, K.P., 2011. phangorn: Phylogenetic analysis in R. Bioinformatics 27, 592-93. https://doi.org/10.1093/bioinformatics/btq706

Schönholzer, F., Hahn, D., Zarda, B., Zeyer, J. 2002. Automated image analysis and in situ hybridization as tools to study bacterial populations in food resources, gut and cast of Lumbricus terrestris L. J. Microbiol. Meth. 48, 53-68. https://doi.org/10.1016/S01677012(01)00345-1

Shen, H., Jiang, G., Wan, X., Li, H., Qiao, Y., Thrush, S., He, P., 2017. Response of the microbial community to bioturbation by benthic macrofauna on intertidal flats. J. Exp. Mar. Biol. Ecol. 488, 44-51. https://doi.org/10.1016/j.jembe.2016.12.010

Šimek, K., Nedoma, J., Znachor, P., Kasalický, V., Jezbera, J., Hornňák, K., Sed'a, J., 2014. A finely tuned symphony of factors modulates the microbial food web of a freshwater reservoir in spring. Limnol Oceanogr 59, 1477-1492. https://doi.org/10.4319/lo.2014.59.5.1477

Smith, H.J., Dieser, M., McKnight, D.M., SanClements, M.D., Foreman, C.M. 2018. Relationship between dissolved organic matter quality and microbial community composition across polar glacial environments. FEMS Microbiol. Ecol. 94, fiy090. https://doi.org/10.1093/femsec/fiy090

Svensson, J.M., Enrich-Prast, A., Leonardson, L., 2001. Nitrification and denitrification in an eutrophic lake sediment bioturbated by oligochaetes. Aquat. Microb. Ecol. 23, 177-86. https://doi.org/10.3354/ame023177

Taylor, J.D., Cunliffe, M., 2015. Polychaete burrows harbour distinct microbial communities in oil-contaminated coastal sediments. Environ. Microbiol. Reports 7, 606-13. https://doi.org/10.1111/1758-2229.12292

Teeling, H., Fuchs, B.M., Becher, D., Klockow, C., Gardebrecht, A., Bennke, C.M., Kassabgy, M., Huang, S., Mann, A.J., Waldmann, J., Weber, M., Klindworth, A., Otto, A., Lange, J., Bernhardt, J., Reinsch, C., Hecker, M., Peplies, J., Bockelmann, F.D., Callies, U., 
Gerdts, G., Wichels, A., Wiltshire, KH, Glöckner, F.O., Schweder, T., Amann, R., 2012. Substrate-controlled succession of marine bacterioplankton populations induced by a phytoplankton bloom. Science 336, 608-11. https://doi.org/10.1126/science.1218344

Langenheder, S., Bulling, M.T., Solan, M., Prosser, J.I., 2010. Bacterial biodiversityecosystem functioning relations are modified by environmental complexity. PloS one 5(5), e10834. https://doi.org/10.1371/journal.pone.0010834

Wavre, M., Brinkhurst, R.O. 1971. Interactions between some tubificid oligochaetes and bacteria found in the sediments of Toronto Harbour, Ontario. J. Fish. Board Canada 28, 335-41. https://doi.org/10.1139/f71-045

Wright, E.S., 2015. DECIPHER: Harnessing local sequence context to improve protein multiple sequence alignment. BMC Bioinformatics 16, 1-14. https://doi.org/10.1186/s12859-015-0749-z

Wright, E.S., 2016. Using DECIPHER v2.0 to analyze big biological sequence data in R. R J. 8, 352-59. https://doi.org/10.32614/rj-2016-025

Zeng, J., Zhao, D.Y., Liu, P., Yu, Z.B., Huang, R., Wu, Q.L. 2014. Effects of benthic macrofauna bioturbation on the bacterial community composition in lake sediments. Can. J. Microbiol. 60, 517-24. https://doi.org/10.1139/cjm-2014-0132

Zhao, Z., Gonsior, M., Schmitt-Kopplin, P., Zhan, Y., Zhang, R., Jiao, N., Chen, F. 2019. Microbial transformation of virus-induced dissolved organic matter from picocyanobacteria: coupling of bacterial diversity and DOM chemodiversity. ISME J. 13, 2551-65. https://doi.org/10.1038/s41396-019-0449-1 
Table 1: Brief description of the four wetlands of the Lyon region (France) where sediments were collected for the present study.

\begin{tabular}{lllll}
\hline Code & Wetland name & Description & Locality & Location \\
\hline SED1 & La Chaume & braided channel of Ain River & Balan & $45^{\circ} 49^{\prime} 51.5^{\prime \prime N} 5^{\circ} 05^{\prime 26.5 " E}$ \\
SED2 & Django & industrial area & Chassieu & $45^{\circ} 44^{\prime} 12.3^{\prime \prime N} 4^{\circ} 57^{\prime} 24.1^{\prime \prime E}$ \\
SED3 & IUT & University campus & Villeurbanne & $45^{\circ} 47^{\prime} 14.2^{\prime \prime} \mathrm{N} 4^{\circ} 52^{\prime} 55.3^{\prime \prime} \mathrm{E}$ \\
SED4 & Minerve & commercial area & Bron & $45^{\circ} 42^{\prime} 52.33^{\prime \prime} \mathrm{N} 4^{\circ} 54^{\prime} 54.0^{\prime \prime} \mathrm{E}$
\end{tabular}




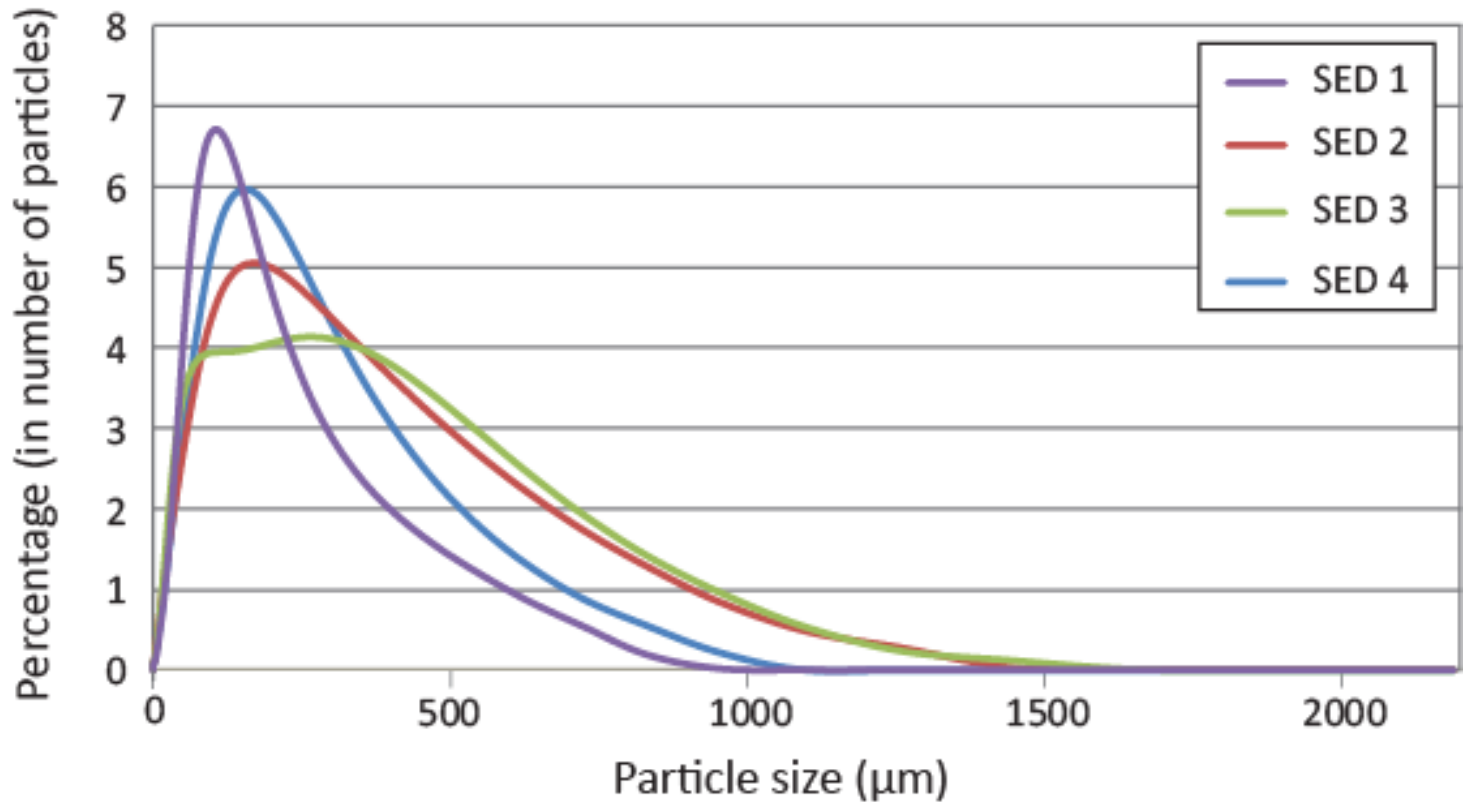

Figure 1: Grain size distribution of the four sediments measured by laser diffractometry. Sediment codes as in Table 1. 

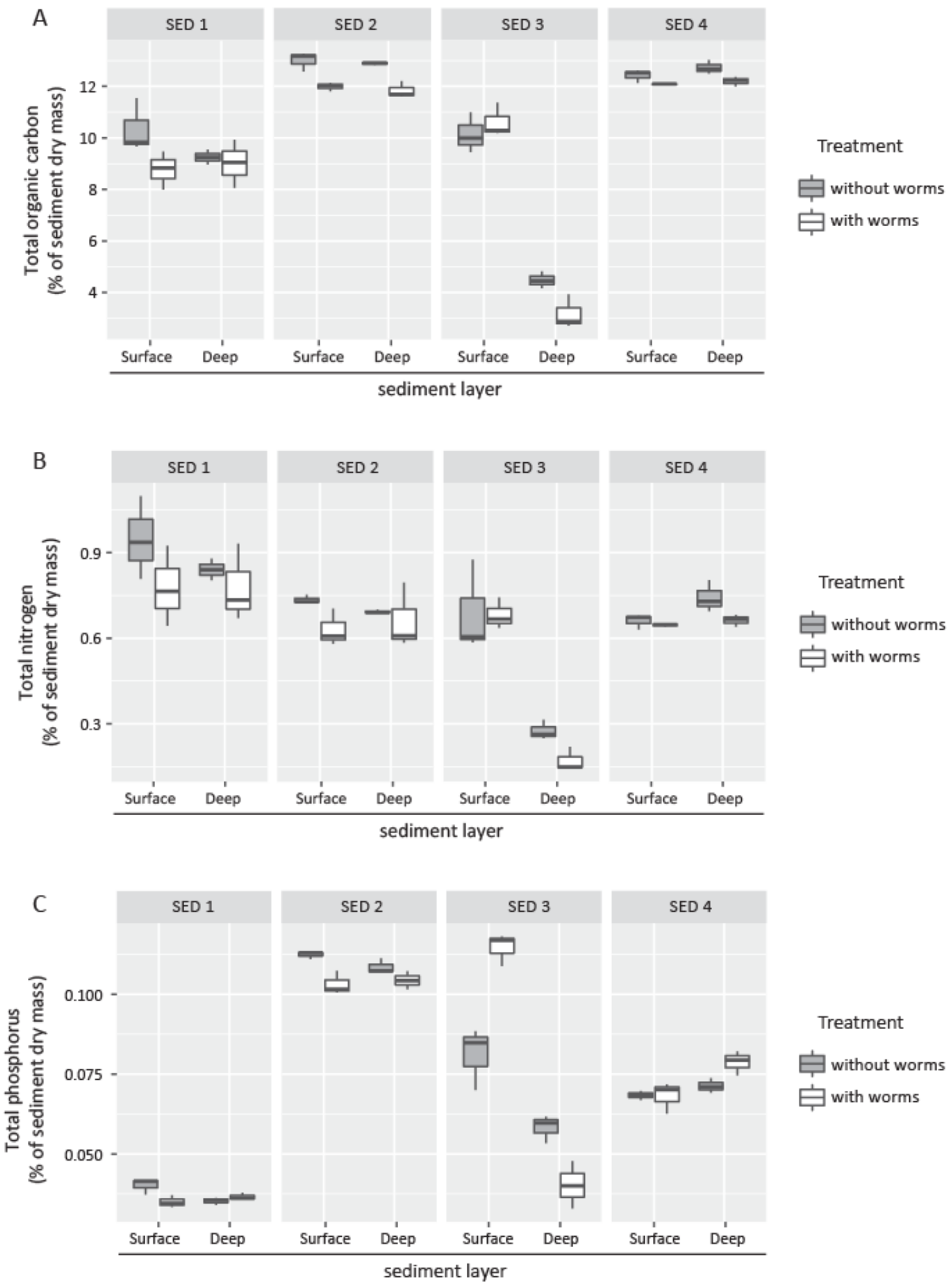

Figure 2: Total organic carbon, nitrogen and phosphorus content in the four sediments separated by treatment (+/- worms) and depth. Grey and white boxplots represent the treatments without and with worms, respectively. Sediment codes as in Table 1. 

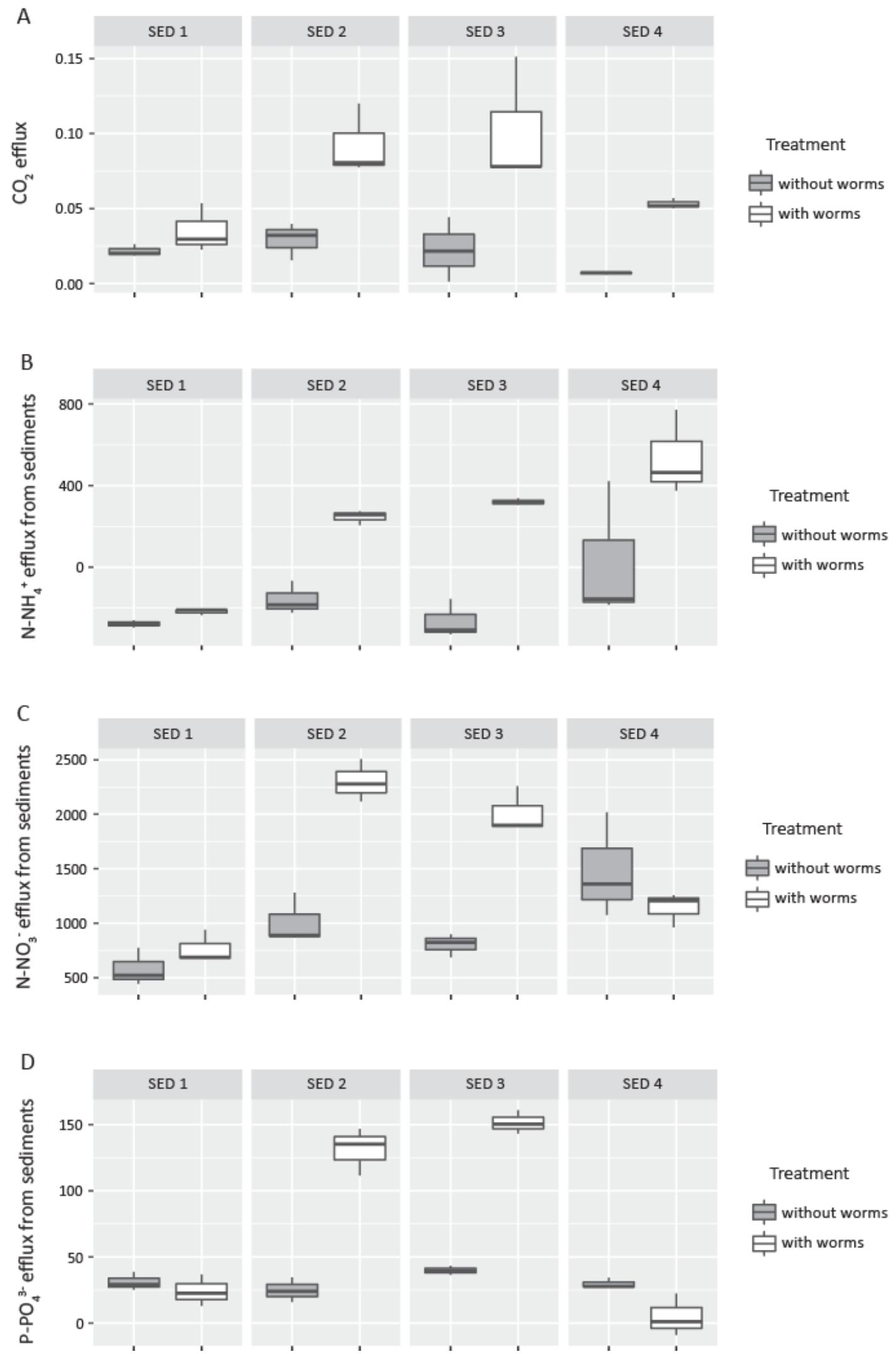

Figure 3: $\mathrm{CO}_{2}, \mathrm{NH}_{4}{ }^{+}, \mathrm{NO}_{3}{ }^{-}$, and $\mathrm{PO}_{4}{ }^{3-}$ fluxes at the water-sediment interface (rates expressed in $\mu \mathrm{mol}$ of $\mathrm{CO}_{2} \cdot \mathrm{s}^{-1} \cdot \mathrm{m}^{-2}$ and in $\mu \mathrm{g}$ of $\mathrm{N}$ or P. $\mathrm{h}^{-1} \cdot \mathrm{m}^{-2}$ for nutrient fluxes). Grey and white boxplots represent the treatments without and with worms, respectively. Sediment codes as in Table 1. 


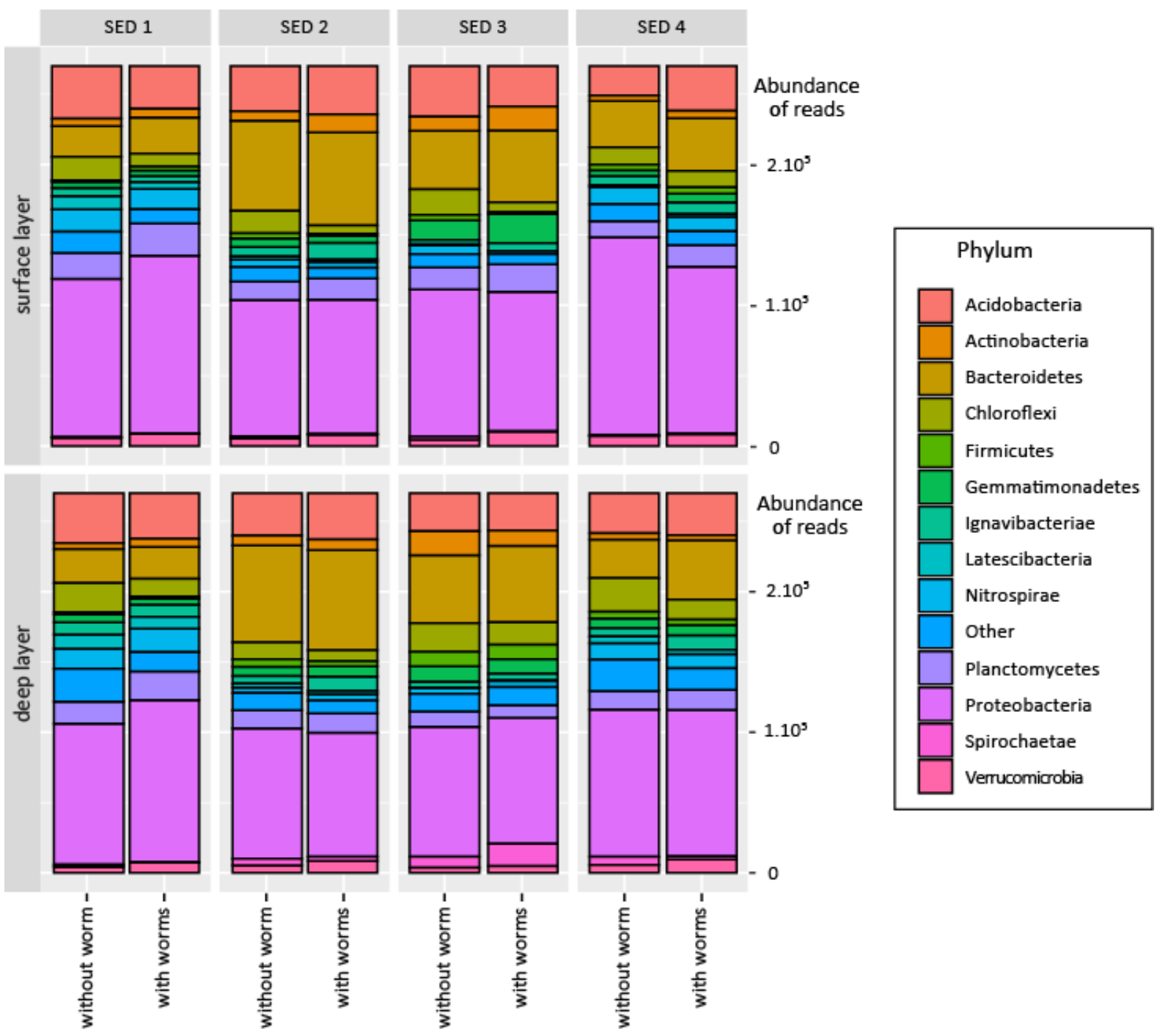

Figure 4: Barplot of bacterial community structure in the four sediments, in the presence or absence of worms. Community structure is represented at the phylum level. Only phyla representing at least $1 \%$ of the reads in at least one sample are represented. Triplicates have been merged. Sample sizes have been normalized to 90,000 sequences in each sample, thus the $\mathrm{x}$-axis ('Abundance') ranges from 0 to 270,000 sequences (i.e., 3 triplicates $* 90,000$ sequences). Sediment codes as in Table 1. 


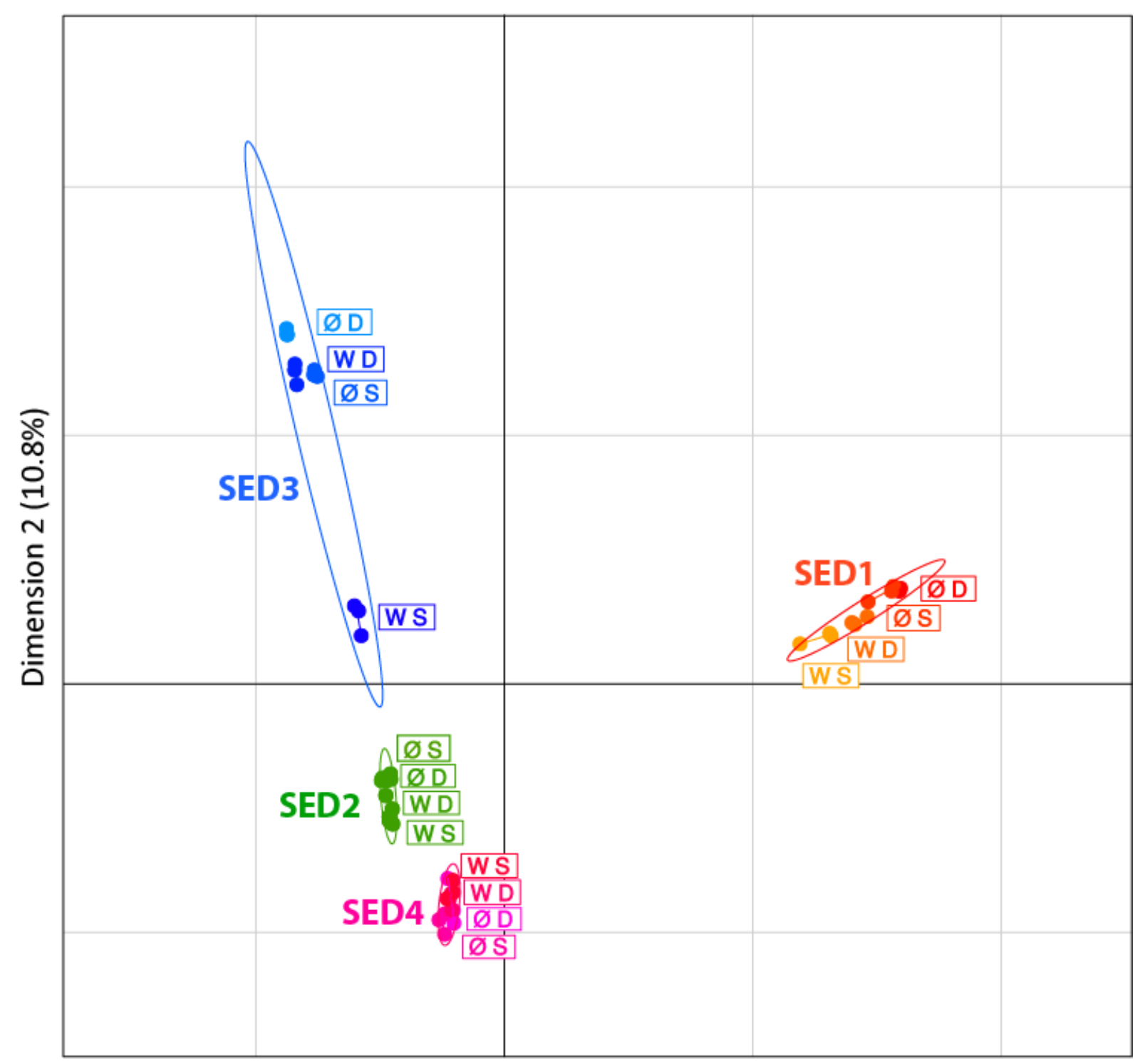

Dimension 1 (13.5\%)

Figure 5: Correspondence analysis of bacterial community structures based on ASV abundances. $\varnothing$ and $\mathrm{W}$ correspond to the treatments without and with worms, respectively. $S$ and D correspond to the surface $(0-1 \mathrm{~cm})$ and deep $(4-5 \mathrm{~cm})$ layers of sediment, respectively. Sediment codes as in Table 1. 

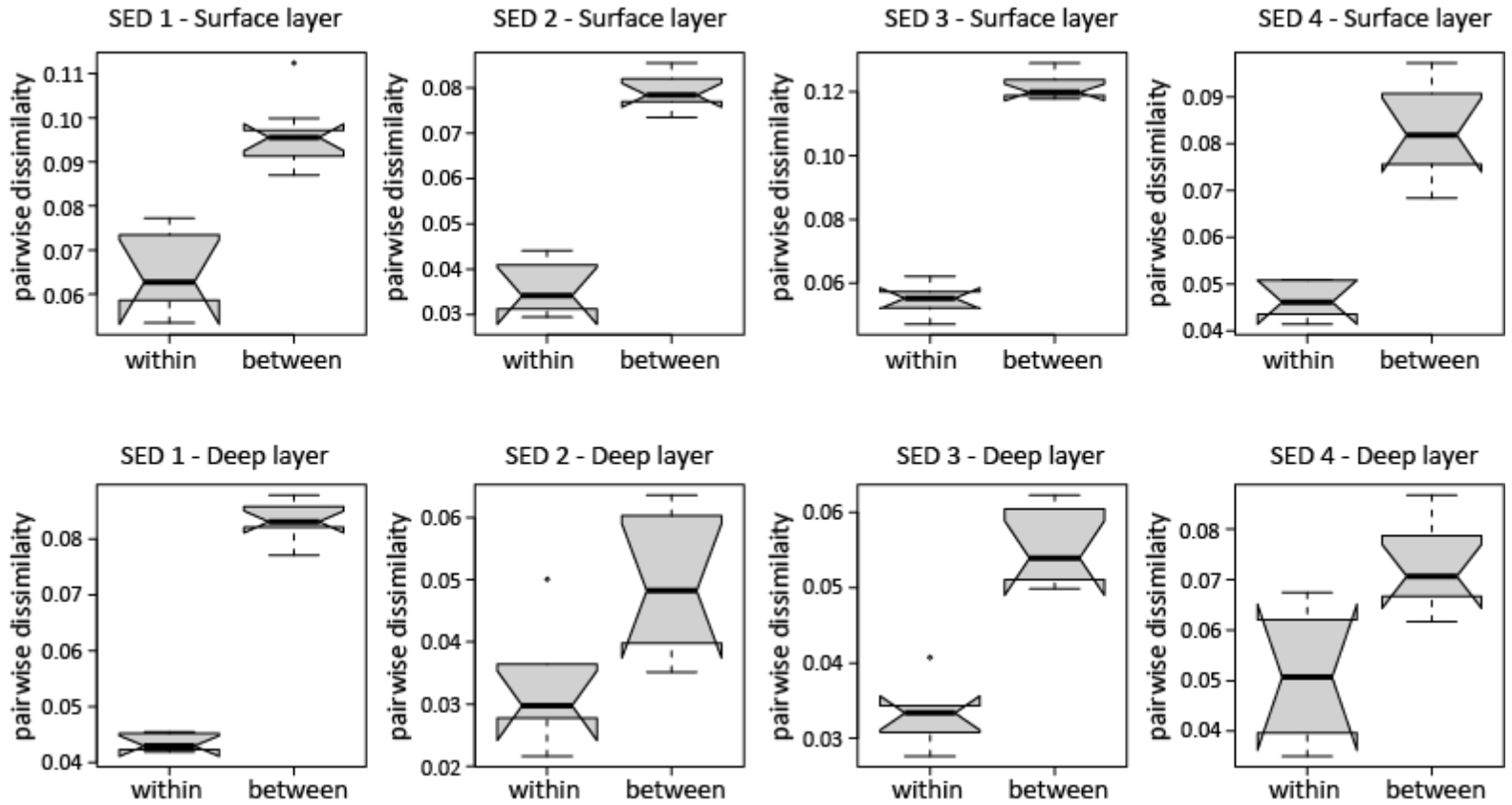

Figure 6: Dissimilarity between bacterial communities caused by bioturbating activity. For each sediment type, dissimilarities (Bray-Curtis distances) were calculated pairwise among the triplicated microcosms with worms, and also among the triplicated microcosms without worms (i.e. "within" dissimilarities); and calculated pairwise between microcosms with and without worms (i.e. "between" dissimilarities). Panels (a) and (b) correspond to the surface and depth layers respectively. Sediment codes as in Table 1. (See M\&M for a detailed explanation of this analysis.) 

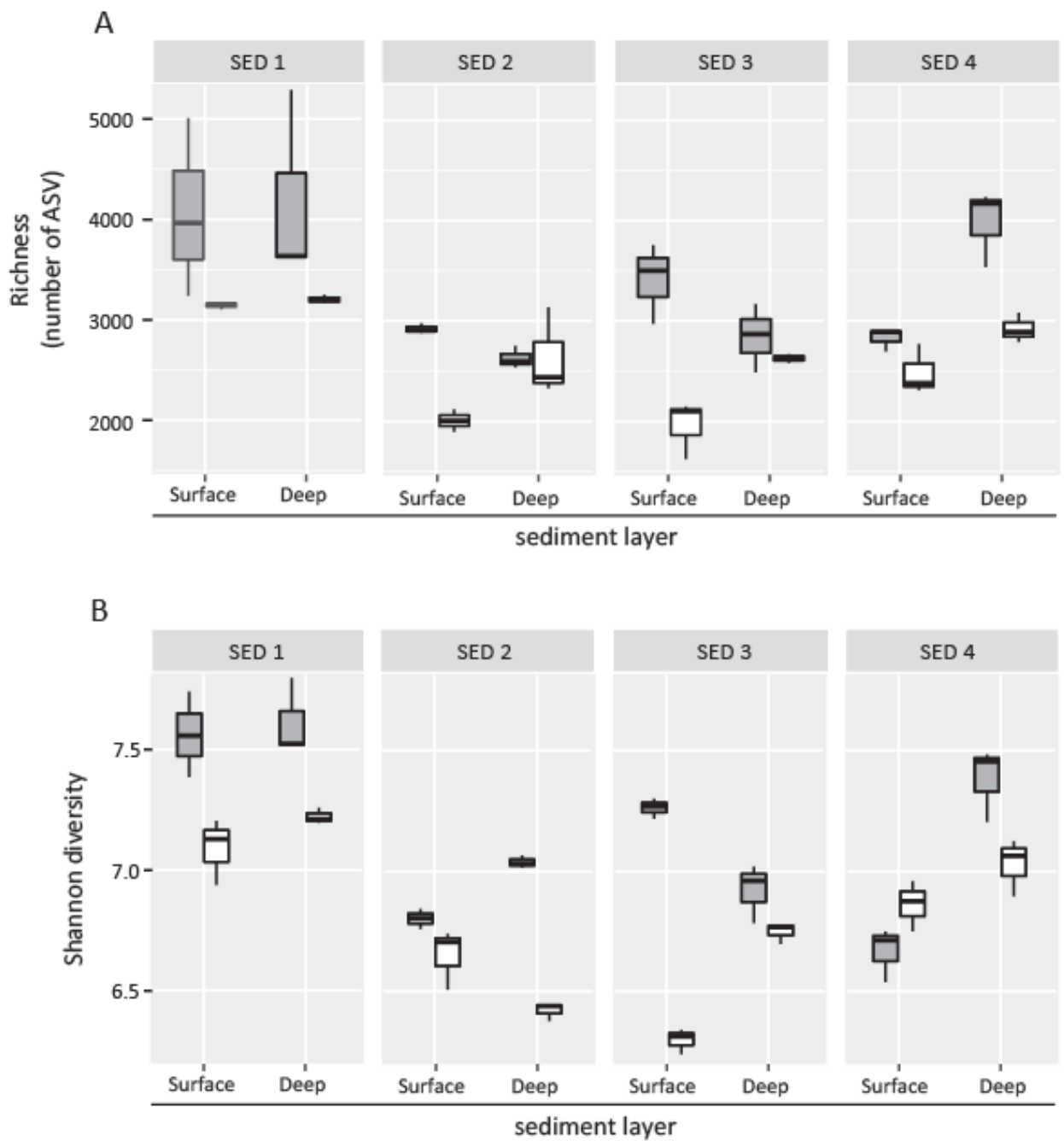

$$
\text { C }
$$

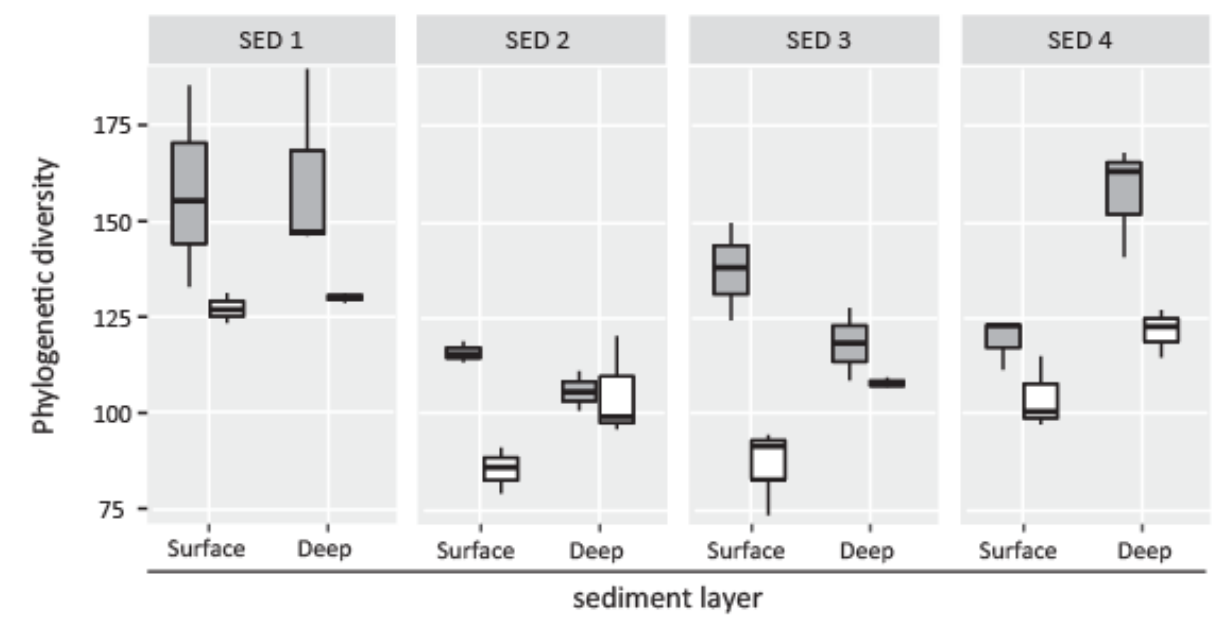

Figure 7: Alpha diversity estimates of bacterial communities at depth 0-1 cm (a) and 4-5 cm (b) in the four sediments. PD represents the Phylogenetic Diversity index. Sediment codes as in Table 1. 